\title{
Estimate of Radiation Release from MIT Reactor with Un-finned LEU Core during Maximum Hypothetical Accident
}

\author{
Kaichao Sun ${ }^{1}$, Lin-wen Hu ${ }^{1}$, Thomas Newton ${ }^{2}$, Erik Wilson ${ }^{3}$, and Arne Olson ${ }^{3}$ \\ 1, Nuclear Reactor Laboratory, Massachusetts Institute of Technology, Cambridge, MA 02139 \\ 2, National Institute of Standards and Technology Center for Neutron Research, Gaithersburg, MD 20899 \\ 3, Nuclear Engineering Division, Argonne National Laboratory Lemont, IL 60439 \\ *Email: kaichao@mit.edu
}

\begin{abstract}
The Massachusetts Institute of Technology Reactor (MITR-II) is a research reactor in Cambridge, Massachusetts designed primarily for experiments using neutron beam and incore irradiation facilities. At $6 \mathrm{MW}$, it delivers neutron flux and energy spectrum comparable to light water reactor (LWR) power reactors in a compact core using highly enriched uranium (HEU) fuel. In the framework of non-proliferation policy, the international community aims to minimize the use of HEU in civilian facilities. Within this context, research and test reactors have started a program to convert HEU fuel to low enriched uranium (LEU) fuel. A new type of LEU fuel based on a high density alloy of uranium and molybdenum (U-10Mo) is expected to allow the conversion of U.S. domestic high performance reactors like MITR. The current study focuses on the impacts of MITR Maximum Hypothetical Accident (MHA), which is also the Design Basis Accident (DBA), with LEU fuel. The MHA for the MITR is postulated to be a coolant flow blockage in the fuel element that contains the hottest fuel plate. It is assumed that the entire active portion of five fuel plates melts. The analysis shows that, within a two-hour period and by considering all the possible radiation sources and dose pathways, the overall off-site dose is $302.1 \mathrm{mrem}$ ( $1 \mathrm{rem}=0.01 \mathrm{~Sv}$ ) Total Effective Dose Equivalent (TEDE) at $8 \mathrm{~m}$ exclusion area boundary (EAB) and a higher dose of $392.8 \mathrm{mrem} T E D E$ is found at $21 \mathrm{mEAB}$. In all cases the dose remains below the 500 mrem total TEDE limit goal based on NUREG1537 guidelines.
\end{abstract}

\section{INTRODUCTION}

The Massachusetts Institute of Technology Research Reactor (MITR) has been in operation since 1958. The first reactor, MITR-I, was a heavy-water moderated and cooled nuclear research reactor. After a re-evaluation of utilization and further core optimization studies, the current reactor design, MITR-II, underwent a major upgrade and began operation in 1976. It is moderated and cooled by light-water and has a heavy-water reflector [1]. MITR-II uses rhomboid-shaped fuel elements (see Figure 1 left). There are 27 in-core positions for fuel elements and/or irradiation experiments (see Figure 1 right). These positions are divided into three radial rings with 3 (A-ring), 9 (B-ring) and 15 (C-ring) rhomboid-shaped areas in each of them. The edge-toedge distances of the three concentric hexagons of the fuel region are $12.4 \mathrm{~cm}, 25.5 \mathrm{~cm}$, and $38.4 \mathrm{~cm}$, respectively. Each fuel element contains 15 fuel plates, which consist of approx. 93\% highly enriched uranium (HEU) sandwiched between sides of aluminum cladding [1]. The fuel meat is $56.8 \mathrm{~cm}$ high, $5.3 \mathrm{~cm}$ wide, and $0.076 \mathrm{~cm}$ thick. The nominal thickness of cladding is $0.038 \mathrm{~cm}$, with longitudinal fins to improve 
heat transfer. There are six control blades and one regulation rod located at the core periphery. They are withdrawn and/or inserted to maintain criticality. All the above-mentioned components are contained in the core tank, which has a cylindrical shape, $52 \mathrm{~cm}$ in diameter and $73 \mathrm{~cm}$ in height. There is a heavy water reflector surrounding it from the sides and the bottom. In addition, a light-water plenum sits above the core. The thermal power of the MITR-II was uprated from 5 MW to 6 MW in 2011 in conjunction with a 20-year license renewal [1].
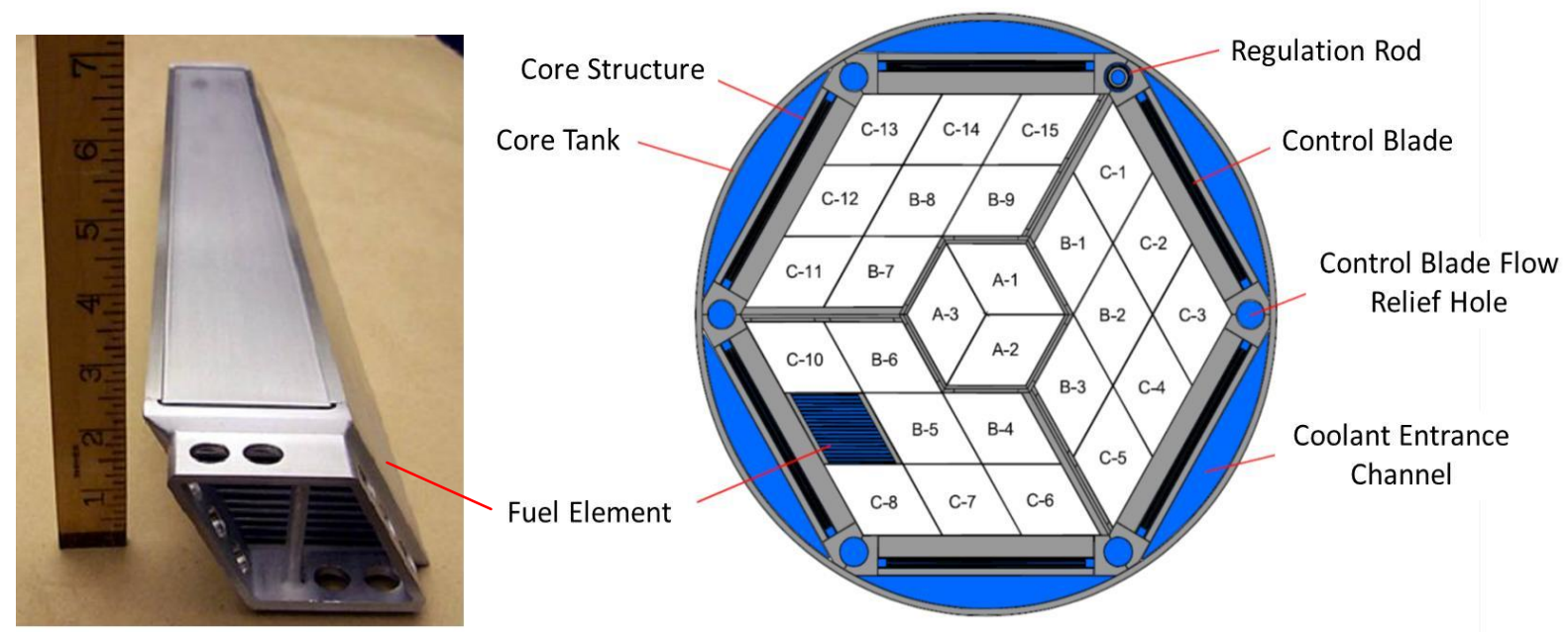

Figure 1. A photo of the rhomboid-shaped fuel elements (left) and the horizontal cross-section of the MITR-II core with indication of different components (right).

In the framework of non-proliferation policy, the international community aims to minimize the use of HEU in civilian facilities. Within this context, research and test reactors have started a program to convert HEU fuel to low enriched uranium (LEU) fuel. A new type of LEU fuel based on a high density alloy of uranium and molybdenum (U-10Mo) is expected to allow the conversion of U.S. domestic high performance reactors like MITR [2] [3].

The current study focuses on the impacts of MITR Maximum Hypothetical Accident (MHA), which is also the Design Basis Accident (DBA). The MHA for the MITR is postulated to be a coolant flow blockage in the fuel element that contains the hottest fuel plate [1]. For the studied LEU core, it is assumed that the entire active portion of five fuel plates melts. This accident could occur if a foreign object were to fall into the core tank and be undetected. In order to cause damage, the object would have to fall through the lower grid plate. This could only occur during a refueling when an element position was open. Fuel element nozzles have multiple openings to allow coolant flow. For the foreign object to block flow to the fuel plates, it would have to pass through one opening, thus putting an effective size limit on the object. Hence, a maximum of five plates would be affected [4].

\section{METHODS}

\subsection{MITR LEU Core Design}

Efforts have been made to design an MITR LEU fuel element with the same outer dimensions that could safely replace the current MITR HEU fuel element and maintain core performance while requiring minimal, if 
any, changes to the reactor system. Designs of the LEU plate-type fuel elements have retained the same rhomboid-shape outer dimensions. One of the LEU elements was designed with 18 thinner plates (recommended from a thermal-hydraulic viewpoint) with $0.51 \mathrm{~mm}$ (20 mils) thick fuel and $0.25 \mathrm{~mm}(10 \mathrm{mils})$ cladding thickness and same longitudinal fins as HEU element. The U-10Mo fuel meat is $19.75 \%$ enriched ${ }^{235} \mathrm{U}$, with a density of $17.0 \mathrm{gram} / \mathrm{cm}^{3}[5]$.

Recent fuel development experience has led to a re-evaluation of the minimum cladding thickness to enhance fabricability. These core and element design activities were undertaken to determine if additional cladding thickness could be incorporated into an MITR LEU element design. Since increased cladding thickness would displace water and degrade core reactivity, removal of the fins was proposed. Removal of the fins would not only increase water to metal ratio in the core, but would also reduce the cost of MITR LEU element by eliminating this fabrication step, which is unique to MITR fuel design among U.S. high performance research reactors. In order to compensate for the loss of heat transfer area, an increased core coolant flow rate has been considered, and reduced fuel thicknesses were introduced in the outer plates of each element to limit heat flux peaking. One final candidate, known as 19B25, was down-selected from a number of potential LEU fuel designs. It consists of $19 \mathrm{LEU}$ fuel plates. Each fuel plate has a nominal total thickness of $1.24 \mathrm{~mm}$ (49 mils). The nominal/standard plate design has fuel meat thickness of $0.64 \mathrm{~mm}$ ( $25 \mathrm{mils})$ and un-finned cladding thickness of $0.30 \mathrm{~mm}$ (12 mils). The code "B" represents the fuel meat thickness reduction for the first three outer plates from each end plate by $45 \%, 30 \%$, and $30 \%$, respectively. A comparison of the HEU and LEU (finned and 19B25) fuel parameters is shown in Table 1. The 19B25 design is now the baseline design, and detailed information can be found in Ref [6].

Table 1. Comparison of current HEU fuel and proposed LEU fuel designs

\begin{tabular}{|c|c|c|c|}
\hline & $\begin{array}{c}\text { HEU - Finned } \\
\left(\mathbf{U A I}_{\mathbf{x}}\right)\end{array}$ & $\begin{array}{c}\text { LEU - Finned } \\
\text { (U-10Mo) }\end{array}$ & $\begin{array}{c}\text { LEU - 19B25 } \\
\text { (U-10Mo) }\end{array}$ \\
\hline U-235 Enrichment (\%) & 93.15 & 19.75 & 19.75 \\
\hline Fuel Density $\left(\mathrm{g} \mathrm{U} / \mathrm{cm}^{3}\right)$ & 1.6 & 15.3 & 15.3 \\
\hline Plates per Element & 15 & 18 & 19 \\
\hline Fuel Thickness (mm) & 0.76 & 0.51 & $\begin{array}{l}0.64 \text { (Full Plates) } \\
0.43 \text { (Middle Plates) } \\
0.33 \text { (End Plates) }\end{array}$ \\
\hline Cladding Thickness (mm) & 0.38 & 0.25 & $\begin{array}{l}0.30 \text { (Full Plates) } \\
0.41 \text { (Middle Plates) } \\
0.46 \text { (End Plates) }\end{array}$ \\
\hline Plate Thickness $(\mathrm{mm})$ & 1.52 & 1.02 & 1.24 \\
\hline Fins on Cladding & Yes & Yes & No \\
\hline Operating Power (MW) & 6.0 & 7.0 & 7.0 \\
\hline Cycle Length (days) & $40-50$ & $55-70$ & $55-70$ \\
\hline
\end{tabular}

\subsection{Regulatory Release Limits and Guidelines for Research Reactors}

The NRC provides guidelines for accident analysis in licensing applications for fuel conversion of research reactors in NUREG-1537, "Guidelines for Preparing and Reviewing Applications for the Licensing of NonPower Reactors" [7]: 
- New or revised analytical procedures may be provided if the information demonstrates that the conversion from HEU fuel could introduce new, unanalyzed accidents, could cause significantly different consequences from a previously postulated accident, or the previously used analytical methods are not appropriate to compare the accidents with acceptable validity. If significantly different analytical methods are used for the LEU-fueled reactor, they may have to be validated by reanalyzing some HEUfueled accidents.

- Projected dose rates and accumulative doses to members of the public in the unrestricted area should not be significantly higher for the proposed LEU-fueled reactor than for the existing HEU-fueled reactor and shall be within acceptable limits.

The LEU fuel conversion does not introduce any new, unanalyzed accidents, nor would it cause significantly different consequences from the previously postulated accident. Some of the analytical methods have been updated for this analysis, thus the analysis results will also be presented for the HEU-fueled core.

The dose acceptance criteria used for research reactors is [7]:

- For research reactors licensed before January 1, 1994, the dose equivalent limits that the US NRC staff accept for accident analysis results are $5 \mathrm{rem}(1 \mathrm{rem}=0.01 \mathrm{~Sv})$ whole body and 30 rem thyroid for occupationally exposed persons and 0.5 rem whole body and 3 rem thyroid for members of the public.

- For research reactors licensed on or after January 1, 1994, occupational exposure limits are discussed in 10 CFR Part 20.1201. Public exposure limits are discussed in 10 CFR Part 20.1301 [8].

- In several instances, the staff has accepted very conservative accident analysis with results greater than the 10 CFR Part 20 dose limits [7].

10 CFR Part 20.1301 lists the annual dose limits for the public from normal operation of a reactor. The specific value cited is 0.1 rem Total Effective Dose Equivalent (TEDE). However, this document also mentions authorization up to an annual dose limit of $0.5 \mathrm{rem}$ based on additional information required of the licensee [8]. The limit of 0.5 rem TEDE corresponds directly to the $0.5 \mathrm{rem}$ whole body annual dose limit cited from NUREG-1537 [7]. In this study, the TEDE levels will be calculated for a two-hour exposure period at the Exclusion Area Boundary (EAB).

The EAB is defined by the fence surrounding the MITR containment building, which is the same boundary used in the past. The boundary is divided into 16 sectors of 45 degrees each, centered on each cardinal wind direction. Figure 2 shows an aerial view of the MITR EAB. 


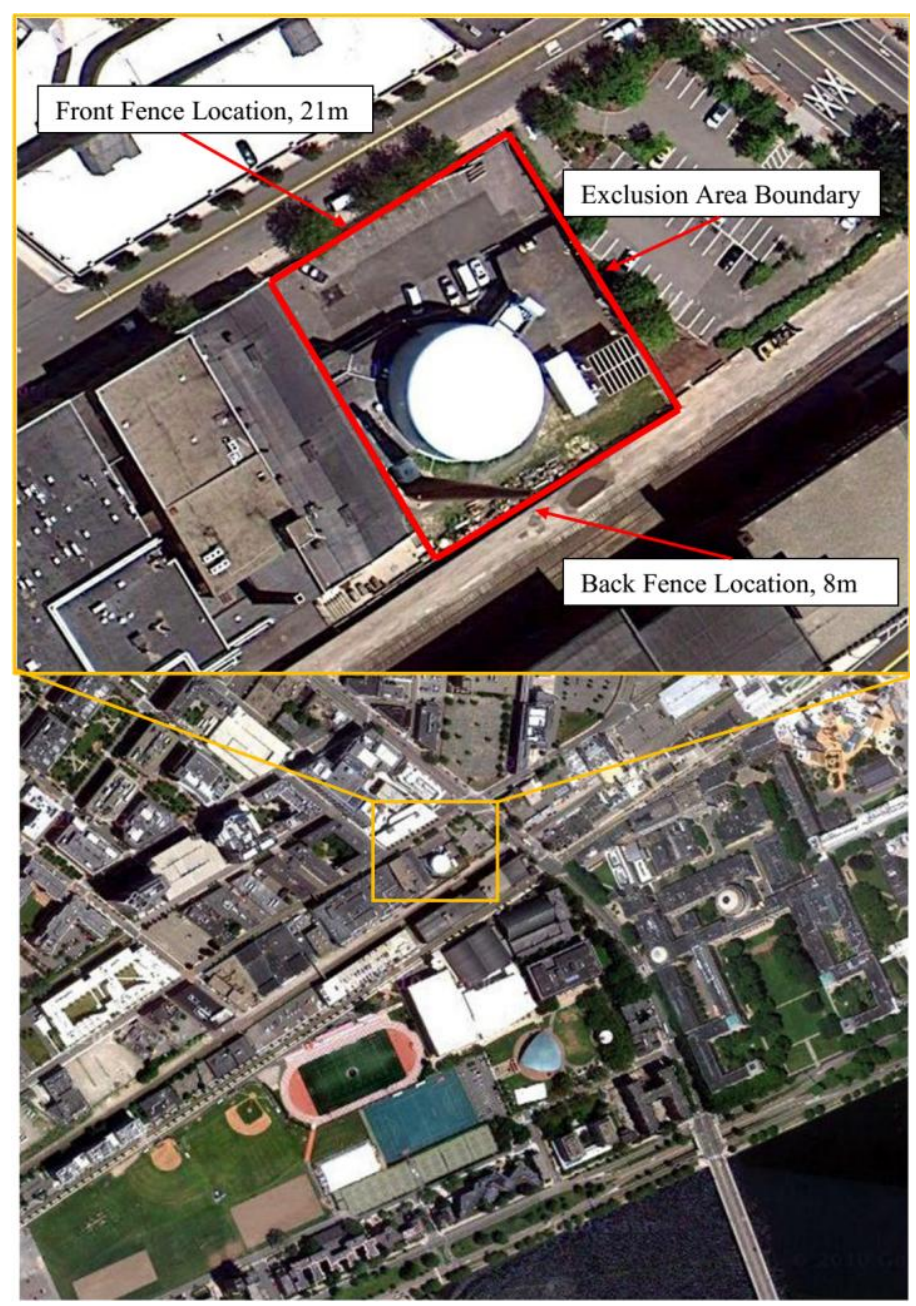

Figure 2. Map of MITR location on campus and exclusion area boundary.

In the previous works, the dose was calculated at the closest points of approach at the front and back fence of the exclusion area [9] [10] [11]. The minimum distance from the MITR containment building to the back fence bordering the railroad tracks is $8 \mathrm{~m}$, and the minimum distance from the MITR containment building to the front fence bordering Albany Street is $21 \mathrm{~m}$. The dose will be calculated primarily at these points in this analysis. Figure 2 illustrates the location of these points on the EAB. Since the MITR is located in an urban region, there is no prescribed distance to the low population zone boundary which is defined for most other sites, thus the primary focus of this work is calculating the dose at the site boundary.

\subsection{Containment Source Determination}

The core inventory was generated with the ORIGEN-S depletion code running simulations representative of the conditions in the MITR core. First, a neutron reaction cross-section library was developed using the SCALE 6.1 module COUPLE (using JEFF 3.0/A library) to update a 238-group library with the flux spectrum from the MCODE model of the MITR core [11]. This library was then used in ORIGEN-S simulations which modeled the MITR power level over an extended irradiation period for a conservative inventory estimate. At the end of the irradiation period, the ORIGEN-S output data was used as the accident source term for the dose calculations. It should be noted that ORIGEN-S is a well-established code with sufficient benchmark and 
$\mathrm{V} \& \mathrm{~V}$ (verification and validation) activities. In addition, coupling ORIGEN-S with state-of-the-art general purpose Monte Carlo code MCNP has been validated using flux wire measurement data at the MITR [12].

The duration of irradiation used will be 4200 MW-day (MWD), which is conservatively assumed for the MITR. The nuclide concentrations from a fresh 22-element core were used as the starting point of the ORIGEN-S run. Table 2 compares the nuclide concentrations for fresh LEU and HEU cores.

Table 2. Input masses for LEU (19B25) and HEU fresh 22 element core (fuel and cladding)

\begin{tabular}{|c|c|c|}
\hline \multirow{2}{*}{ Nuclides } & \multicolumn{2}{|c|}{ Full Core Mass $(\mathrm{kg})$} \\
\cline { 2 - 3 } & LEU (19B25) & HEU \\
\hline $\mathrm{U}-235$ & 21.30 & 11.22 \\
\hline $\mathrm{U}-238$ & 86.38 & 0.85 \\
\hline $\mathrm{Al}$ & 24.49 & 42.85 \\
\hline $\mathrm{Mo}$ & 10.75 & - \\
\hline $\mathrm{Zr}$ & 4.16 & - \\
\hline
\end{tabular}

The postulated accident scenario involves only a small portion of the core melting during the accident. Four plates in the hottest region of the HEU core were assumed to melt. However, each LEU element will contain 19 plates rather than 15 . The fuel element occupies the same space resulting in closer spacing between the fuel plates. This closer spacing leads to five plates becoming blocked during the accident rather than four. For accidents which do not involve the entire core, the NRC regulations specify that the fission product fraction of the inventory released is equal to the fraction of the affected plates times the radial peaking factor [13]. The radial peaking factor $\left(\mathrm{F}_{\mathrm{s}}\right)$ for the HEU core was 1.46. The radial peaking factor for the LEU core was calculated by finding the group of five adjacent plates whose average power was the greatest. This average power was compared to the average power of all the plates in the core to yield the peaking factor. The representative LEU core states, which take into account not only beginning-of-life (BOL) but also middle-oflife (MOL) and end-of-life (EOL), are considered in this study. The selection for the MOL is due to the highest heat flux at the peak spot and the selection of the EOL is because of the consideration of burnup magnitude [6]. The radial peaking factors for five adjacent plates in these corresponding fuel cycle states are presented in Table 3. Finally, the proposed radial peaking factor of the 19B25 LEU fuel for the MHA analysis is conservatively set to 1.41. The overall fraction of the entire core inventories assumed to melt is expressed in Eq. 1.

Table 3. Radial Peaking Factors for five adjacent plates of the 19B25 LEU core

\begin{tabular}{|c|c|}
\hline \multicolumn{2}{|c|}{ LEU - 19B25 } \\
Radial Peaking Factor \\
(five adjacent plates) \\
\hline BOL & 1.367 \\
MOL (Cycle 189 - BOC) & 1.404 \\
EOL (Cycle 185 - EOC) & 1.311 \\
\hline Used in analysis & $\mathbf{1 . 4 1}$ \\
\hline
\end{tabular}




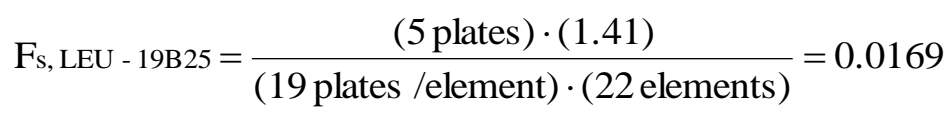

\section{Source Term of Airborne Release from Containment}

Fission Product release fractions reflect the portion of a particular nuclide which leaves the fuel and enters either the coolant or containment. In order to maintain consistency with the previous work, a multi-step release from fuel to coolant and from coolant to containment was considered. Most of the adopted release fractions are carried on from MITR Safety Analysis Report (SAR) [1]. The only exception is to assume $100 \%$ halogens will be released from the melted fuel, instead of $90 \%$ used in the SAR. Nevertheless, this leads to a more conservative consideration. The released fraction breakdowns of the fuel-to-coolant, coolant-tocontainment, and remaining airborne in containment atmosphere are presented in Table 4.

Table 4. Fission product release fractions [1]

\begin{tabular}{|c|c|c|c|}
\hline Element Group & $\begin{array}{c}\text { Fraction Released } \\
\text { from Melted Fuel } \\
\left(\mathrm{F}_{\mathrm{f}}\right)(19 \mathrm{~B} 25)\end{array}$ & $\begin{array}{c}\text { Fraction Released } \\
\text { from Primary } \\
\text { Coolant System } \\
\left(\mathrm{F}_{\mathrm{p}}\right)(19 \mathrm{~B} 25)\end{array}$ & $\begin{array}{c}\text { Fraction Remaining } \\
\text { Airborne in } \\
\text { Containment } \\
\text { Atmosphere } \\
\left(\mathrm{F}_{\mathrm{c}}\right)(19 \mathrm{~B} 25)\end{array}$ \\
\hline Noble Gases & 1.0 & 1.0 & 1.0 \\
\hline Halogens & $1.0 *$ & 0.03 & 0.3 \\
\hline Alkali Metals & 0.9 & 0.03 & 0.3 \\
\hline Tellurium group & 0.23 & 0.03 & 0.9 \\
\hline Barium, Strontium & 0.01 & 0.03 & 0.9 \\
\hline Noble Metals & 0.01 & 0.03 & 0.9 \\
\hline Lanthanides & 0.0001 & 0.03 & 0.9 \\
\hline Cerium group & 0.0001 & 0.03 & 0.9 \\
\hline
\end{tabular}

* The MITR SAR adopts 0.9 .

The fuel to containment release fractions are the products of the intermediate components. The final values for 19B25 LEU core are summarized in the last column of Table 5. They are also compared with the values introduced in the previous works. The first two columns provide the data from NRC Regulatory Guide (Reg. Gd.) 1.183 and 1.195 for fuel to coolant release fractions from a pressurized water reactor (PWR) design basis accident LOCA (Loss-of-Coolant Accident). The following two columns list the values for fuel-tocontainment as a product of the Reg. Gd. values and the MITR SAR value for $F_{p}$ given in Table 4. The third to last column provides the plate-type fuel release fractions with the values for $\mathrm{F}_{\mathrm{f}}$ from plate-type design and the MITR SAR values for $\mathrm{F}_{\mathrm{p}}$ from Table 4. 
Table 5. Summary of fuel to containment fission product release fractions

\begin{tabular}{|c|c|c|c|c|c|c|}
\hline Element & $\begin{array}{c}\text { Reg. Gd. } \\
\mathbf{1 . 1 8 3}\end{array}$ & $\begin{array}{c}\text { Reg. Gd. } \\
\mathbf{1 . 1 9 5}\end{array}$ & $\begin{array}{c}\text { Reg. Gd. } \\
\mathbf{1 . 1 8 3} \text {.SAR }\end{array}$ & $\begin{array}{c}\text { Reg. Gd. } \\
\mathbf{1 . 1 9 5} \text {.SAR }\end{array}$ & Plate & $\mathbf{1 9 B 2 5}$ \\
\hline $\mathrm{Xe}$ & 1 & 1 & 1 & 1 & 1 & $\mathbf{1}$ \\
\hline $\mathrm{Kr}$ & 1 & 1 & 1 & 1 & 1 & $\mathbf{1}$ \\
\hline $\mathrm{I}$ & 0.4 & 0.5 & 0.012 & 0.015 & 0.027 & $\mathbf{0 . 0 3}$ \\
\hline $\mathrm{Br}$ & 0.4 & 0 & 0.012 & 0 & 0.027 & $\mathbf{0 . 0 3}$ \\
\hline $\mathrm{Cs}$ & 0.3 & 0 & 0.009 & 0 & 0.0225 & $\mathbf{0 . 0 2 7}$ \\
\hline $\mathrm{Rb}$ & 0.3 & 0 & 0.009 & 0 & 0.0225 & $\mathbf{0 . 0 2 7}$ \\
\hline $\mathrm{Te}$ & 0.05 & 0 & 0.0015 & 0 & 0.021 & $\mathbf{0 . 0 0 7}$ \\
\hline $\mathrm{Sb}$ & 0.05 & 0 & 0.0015 & 0 & 0.021 & $\mathbf{0 . 0 0 7}$ \\
\hline $\mathrm{Se}$ & 0.05 & 0 & 0.0015 & 0 & 0.021 & $\mathbf{0 . 0 0 7}$ \\
\hline $\mathrm{Ba}$ & 0.02 & 0 & 0.0006 & 0 & 0.0003 & $\mathbf{0 . 0 0 0 3}$ \\
\hline $\mathrm{Sr}$ & 0.02 & 0 & 0.0006 & 0 & 0.0003 & $\mathbf{0 . 0 0 0 3}$ \\
\hline $\mathrm{Ru}$ & 0.0025 & 0 & 0.000075 & 0 & 0.0003 & $\mathbf{0 . 0 0 0 3}$ \\
\hline $\mathrm{Rh}$ & 0.0025 & 0 & 0.000075 & 0 & 0.0003 & $\mathbf{0 . 0 0 0 3}$ \\
\hline $\mathrm{Pd}$ & 0.0025 & 0 & 0.000075 & 0 & 0.0003 & $\mathbf{0 . 0 0 0 3}$ \\
\hline $\mathrm{Mo}$ & 0.0025 & 0 & 0.000075 & 0 & 0.0003 & $\mathbf{0 . 0 0 0 3}$ \\
\hline $\mathrm{Tc}$ & 0.0025 & 0 & 0.000075 & 0 & 0.0003 & $\mathbf{0 . 0 0 0 3}$ \\
\hline $\mathrm{La}$ & 0.0002 & 0 & 0.000006 & 0 & 0.000003 & $\mathbf{0 . 0 0 0 0 0 3}$ \\
\hline $\mathrm{Zr}$ & 0.0002 & 0 & 0.000006 & 0 & 0.000003 & $\mathbf{0 . 0 0 0 0 0 3}$ \\
\hline $\mathrm{Nd}$ & 0.0002 & 0 & 0.000006 & 0 & 0.000003 & $\mathbf{0 . 0 0 0 0 0 3}$ \\
\hline $\mathrm{Eu}$ & 0.0002 & 0 & 0.000006 & 0 & 0.000003 & $\mathbf{0 . 0 0 0 0 0 3}$ \\
\hline $\mathrm{Nb}$ & 0.0002 & 0 & 0.000006 & 0 & 0.000003 & $\mathbf{0 . 0 0 0 0 0 3}$ \\
\hline $\mathrm{Pm}$ & 0.0002 & 0 & 0.000006 & 0 & 0.000003 & $\mathbf{0 . 0 0 0 0 0 3}$ \\
\hline $\mathrm{Pr}$ & 0.0002 & 0 & 0.000006 & 0 & 0.000003 & $\mathbf{0 . 0 0 0 0 0 3}$ \\
\hline $\mathrm{Sm}$ & 0.0002 & 0 & 0.000006 & 0 & 0.000003 & $\mathbf{0 . 0 0 0 0 0 3}$ \\
\hline $\mathrm{Y}$ & 0.0002 & 0 & 0.000006 & 0 & 0.000003 & $\mathbf{0 . 0 0 0 0 0 3}$ \\
\hline $\mathrm{Cm}$ & 0.0002 & 0 & 0.000006 & 0 & 0.000003 & $\mathbf{0 . 0 0 0 0 0 3}$ \\
\hline $\mathrm{Am}$ & 0.0002 & 0 & 0.000006 & 0 & 0.000003 & $\mathbf{0 . 0 0 0 0 0 3}$ \\
\hline $\mathrm{Ce}$ & 0.0005 & 0 & 0.000015 & 0 & 0.000003 & $\mathbf{0 . 0 0 0 0 0 3}$ \\
\hline $\mathrm{Pu}$ & 0.0005 & 0 & 0.000015 & 0 & 0.000003 & $\mathbf{0 . 0 0 0 0 0 3}$ \\
\hline $\mathrm{Np}$ & 0.0005 & 0 & 0.000015 & 0 & 0.000003 & $\mathbf{0 . 0 0 0 0 0 3}$ \\
\hline & & & & & & \\
\hline
\end{tabular}

It should be noted that a linear evaporation process for the coolant-to-containment radiation source release (noble gas elements excluded) is assumed in the current study; whereas an instant release scenario is adopted in the MITR SAR. The effect of applying linear evaporation rate of the primary coolant has been quantified in the Ref [4]. In any case, the linear evaporation process is still considered as a very conservative consideration, since no delay time for the fission products release is taken as credit during the MHA development.

\section{Source Term Contributed to Gamma Dose}

The nuclides that remain in containment during the accident create a gamma source term. The magnitude of the gamma source term decreased over the duration of the accident due to radioactive decay as well as release of airborne nuclides from containment through the pressure relief system and containment leakage.

ORIGEN-S computed a time-dependent gamma source term over the decay period of the simulation. The calculations include all the important nuclides that contribute to over $99 \%$ total activities. The source terms are created in a discrete manner for each 10-minute interval. This is to take into account the radioactive decay as well as release of airborne nuclides from containment through the pressure relief system and containment leakage. The first source term value listed by ORIGEN-S corresponds to the first time step rather than the 
onset of the accident. The first time step used in this work was 10 minutes into the accident. In order to integrate the source term over the duration of the accident, the value at 10 minutes was assumed to be constant over the first time interval, from 0 to 10 minutes [11]. This treatment does not fully encompass the contributions from nuclides with very short half-lives. However, this treatment is justified since only nuclides with a half-life greater than 15 minutes were used in the previous work [10]. Due to the finite time required for the fuel to melt and for fission products to be released, neglecting the spike in the source term for the first 10 minutes is a reasonable assumption. For the remaining time intervals beyond the first 10 minutes, trapezoidal integration was used based on the discrete source term strength listed at each time step. Since the nuclide activities are generally decreasing over the accident, the trapezoidal integration technique is conservative compared to the classical exponential treatment of decay processes.

\subsection{Atmospheric Dose}

Any nuclides released from containment during the accident would contribute to the public dose at the EAB and at locations further away from the reactor. This analysis focused on the release through two pathways: pressure relief venting through the stack and containment leakage. The dose from exposure to airborne nuclides depends on the ground level concentration, the nuclide release rate, and dose conversion factors corresponding to the nuclides in the radiation cloud. Key equations for calculating atmospheric dose are summarized in this sub-section. More detailed method descriptions can be found in the earlier studies, i.e. Refs [9] [10] [11].

\section{Nuclide Exit Rate from Containment}

Dose calculations from exposure to airborne nuclides require the pollutant exit rate from containment in units of $\mathrm{Ci} / \mathrm{s}\left(1 \mathrm{Ci}=3.7 \times 10^{10} \mathrm{~Bq}\right)$. The exit rate of nuclide $i$ is defined by Eq. 2 .

$$
\mathrm{QR}^{i}(t)=\lambda_{L} \cdot \mathrm{C}_{i}(t)
$$

Eq. 2

where

$\lambda_{L}: \quad$ is the volumetric air leakage rate from containment $\left[\mathrm{m}^{3} / \mathrm{s}\right]$,

$\mathrm{C}_{i}(t): \quad$ is the airborne concentration in side containment of nuclide $i$ at time $t\left[\mathrm{Ci} / \mathrm{m}^{3}\right]$.

Airborne nuclides could escape containment during the MHA through two pathways, first through containment building leakage through a hypothetical crack or building seal failure, or through containment pressure relief using the pressure relief system. In order to calculate the values for $\mathrm{Q}_{\mathrm{R}}{ }^{i}(t)$ through each pathway, first the volumetric air flow rates were defined, and then the flow rates were used to calculate the time-dependent airborne nuclide concentration inside containment.

During the MHA the plenum monitors would trip the exhaust dampers, sealing the building automatically. The building could also be sealed manually from the control room. With the building sealed, changes in containment or atmospheric temperature could cause the containment pressure to increase. If the containment pressure reached the design set-point of $2.0 \mathrm{psig}(1 \mathrm{psig}=6.895 \mathrm{kpa})$, safe pressure relief can be achieved via the pressure relief system. The pressure relief system can discharge containment air through a filter to the base of the ventilation exhaust stack. It was shown in the safety analysis of the system that the pressure relief system can be safely operated during the MHA.

The containment pressure relief system exhaust line contains two high-efficiency absolute particulate air filters that are $99 \%$ efficient for particle sizes of 0.3 microns, in addition to an activated charcoal filter that is $99 \%$ efficient for removal of elemental iodine. The fractions of nuclides penetrating the filters of the pressure relief system, $f$, are (5):

- $100 \%$ of noble gases and $\mathrm{Br}$ 
- $5 \%$ of iodine

- $50 \%$ of all other isotopes.

The flow rate through the system would be dictated by the pressure difference between containment and the atmosphere, which is assumed to be $2.0 \mathrm{psig}$. Experimental data found that the flow rate at $2.0 \mathrm{psig}$ through filter 1 is $355 \mathrm{ft}^{3} / \mathrm{min}(\mathrm{cfm})$ and through filter 2 is $330 \mathrm{cfm}\left(1 \mathrm{cfm}=471.95 \mathrm{~cm}^{3} / \mathrm{s}\right)$ [10]. The average leakage rate through the stack, $\lambda_{L} \mathrm{~S}$, is $342.5 \mathrm{cfm}$. (The superscript $\mathrm{S}$ indicates the stack.) Considering containment volume of $4730 \mathrm{~m}^{3}, \lambda_{L}{ }^{\mathrm{S}}=3.42 \times 10^{-5} \mathrm{~V} / \mathrm{s}$. (V stands for containment volume.)

The maximum permissible leakage rate from containment is $1 \%$ of the building volume per day per psi of overpressure. An integral air leakage test of containment is conducted periodically to ensure compliance with the criteria. At the accident onset, the containment building is assumed to reach its design set point instantly. The leakage rate is assumed to be the maximum permissive value, i.e. $1 \%$ of building volume per day per psig of overpressure. This containment leakage rate is obtained as $\lambda_{L}{ }^{\mathrm{G}}=2.3 \times 10^{-7} \mathrm{~V} / \mathrm{s}$. (The superscript $\mathrm{G}$ indicates the "ground" level.)

\section{Atmospheric Dispersion}

The methods (formulas) and the coefficients for atmospheric dispersions from stack release and containment leakage remain the same as previous MITR safety analysis, because the MITR containment design and its pressure relief system remain unchanged. It should be noted that the primary change is the source term for the dose estimations, since it becomes different due to using the newer (i.e. 19B25) LEU fuel.

Atmospheric dispersion of nuclides is primarily dependent on meteorological conditions such as ambient temperature, wind speed, time of day, and cloud cover, as well as the gas velocity and temperature exiting the stack. The maximum ground-level concentration may be beyond the EAB, thus the atmospheric concentration values were calculated at various distances. The basic equation for atmospheric diffusion from an elevated release (i.e. from stack) is given by Eq. 3. It shows the dependency of the ground level concentration on the various parameters in the atmospheric dispersion model. The most dominant term will be the vertical dispersion coefficient as it appears in both the denominator and the exponential term. The lateral dispersion coefficient appears in the denominator which shows that a higher dispersion coefficient will decrease the peak concentration. Mean wind speed is related to atmospheric stability class, where higher wind speeds will result in more dispersion and lower peak concentrations. The atmospheric dispersion from containment leakage can be estimated by Eqs. 4 and 5, for reduced wake effect and full wake effect, respectively. Due to the channeling effect of the adjacent buildings, it is expected that the turbulent mixing of the wake effect for the MITR will be more pronounced than that of a containment building located in the open countryside [9]. Therefore, doses were calculated using the $\chi / Q$ values from Eq. 5 representing the full wake effect treatment. This methodology has been used in the previous dose calculations in the MIT SAR, thus it was used again for this work. The adopted parameters in these equations are defined in Table 6.

$$
\begin{aligned}
& \frac{\chi}{Q}=\frac{1}{\pi \overline{\mathrm{Uh}} \sigma_{\mathrm{y}} \sigma_{\mathrm{z}}} \exp \left[-\frac{\mathrm{hs}^{2}}{2 \sigma_{\mathrm{z}}{ }^{2}}\right] \\
& \frac{\chi}{Q}=\frac{1}{\overline{\mathrm{Uh}}\left(3 \pi \sigma_{\mathrm{y}} \sigma_{\mathrm{z}}\right)} \\
& \frac{\chi}{Q}=\frac{1}{\overline{\mathrm{Uh}}\left(\pi \sigma_{\mathrm{y}} \sigma_{\mathrm{z}}+\mathrm{A} / 2\right)}
\end{aligned}
$$

where $\quad \chi \quad$ is the ground level concentration $\left[\mathrm{Ci} / \mathrm{m}^{3}\right]$, 
$Q \quad$ is the pollutant exit rate $[\mathrm{Ci} / \mathrm{s}]$,

$\mathrm{U}_{\mathrm{h}} \quad$ is the wind speed at the release height $[\mathrm{m} / \mathrm{s}]$,

$\mathrm{h}_{\mathrm{s}} \quad$ is the actual stack height of $46 \mathrm{~m}$,

$\sigma_{\mathrm{y}} \quad$ is the lateral plume dispersion coefficient [m],

$\sigma_{\mathrm{z}} \quad$ is the vertical plume dispersion coefficient [m],

A is the smallest vertical cross-section area of the reactor building of $314 \mathrm{~m}^{2}$.

Table 6. Dispersion coefficients and average wind speeds for various atmospheric dispersions

\begin{tabular}{|c|r|c|c|c|c|}
\hline $\begin{array}{c}\text { Pasquill } \\
\text { Stability } \\
\text { Category }\end{array}$ & Stability Description & $\begin{array}{c}\boldsymbol{\sigma}_{\mathbf{y}}(\boldsymbol{x}) \\
\boldsymbol{x} \text { distance from } \\
\text { source [m] }\end{array}$ & $\begin{array}{c}\boldsymbol{x} \text { : distance from } \\
\text { source [m] }\end{array}$ & $\begin{array}{c}\text { Average } \\
\text { Wind } \\
\text { Speed } \\
{[\mathbf{k n o t} / \mathbf{s}]}\end{array}$ & $\begin{array}{c}\text { Relative } \\
\text { Frequency }\end{array}$ \\
\hline A & Very unstable & $0.22 x(1+0.0001 x)^{-0.5}$ & $0.20 x$ & 3.8 & 0.0823 \\
\hline B & Moderately unstable & $0.16 x(1+0.0001 x)^{-0.5}$ & $0.12 x$ & 6.4 & 1.83 \\
\hline C & Slightly unstable & $0.11 x(1+0.0001 x)^{-0.5}$ & $0.08 x(1+0.0002 x)^{-0.5}$ & 9.2 & 8.30 \\
\hline D & Neutral & $0.08 x(1+0.0001 x)^{-0.5}$ & $0.06 x(1+0.0015 x)^{-0.5}$ & 11.9 & 73.94 \\
\hline E & Slightly stable & $0.06 x(1+0.0001 x)^{-0.5}$ & $0.03 x(1+0.0003 x)^{-1}$ & 7.7 & 12.03 \\
\hline F & Moderately stable & $0.04 x(1+0.0001 x)^{-0.5}$ & $0.16 x(1+0.0003 x)^{-1}$ & 4.6 & 3.81 \\
\hline
\end{tabular}

\section{Dose Calculation from Exposure to Airborne Nuclides}

The Total Effective Dose Equivalent (TEDE) is comprised of the Committed Effective Dose Equivalent (CEDE) due to inhalation and the Deep Dose Equivalent (DDE) due to air submersion in a semi-infinite cloud of different nuclides.

The CEDE dose over a time interval $\Delta t$ is given by:

$$
\text { Dose }=\mathrm{BRCC}_{\mathrm{R}} \cdot\left(\frac{\chi}{Q}\right) Q_{R}^{S}(\Delta t)
$$

where $\quad B_{R} \quad$ is the breathing rate $\left[\mathrm{m}^{3} / \mathrm{s}\right]$,

$\mathrm{C}_{\mathrm{C}} \quad$ is the CEDE dose equivalent for a particular nuclide [rem/Ci],

$Q_{R}{ }^{S}(\Delta t)$ is the pollutant which exited source over time $\Delta t[\mathrm{Ci}]$.

The breathing rate is assumed to be $3.5 \times 10^{-4} \mathrm{~m}^{3} / \mathrm{s}$ over the first 8 hours of the accident [1]. The values for $\mathrm{C}_{\mathrm{C}}$ can be found in the appendix of Ref [11]. These CEDE dose coefficients are obtained from Federal Guidance Report No. 11, Table 2.1, under column "effective". The CEDE coefficients represent a weighted dose implication based on exposure spread over a variety of organs. Some nuclides have different dose coefficients depending on the class of particle, which represents the length of time the nuclide would be active within the body. The class depends on the chemical form of the nuclide when it is inhaled. Since there are hundreds of nuclides included in these analysis, the class with the highest dose coefficient was selected for each nuclide. This is a conservative assumption.

The DDE dose over a time interval $\Delta t$ is given by:

$$
\text { Dose }=\mathrm{CDDE} \cdot\left(\frac{\chi}{Q}\right) Q_{R}^{S}(\Delta t)
$$


where $\quad \mathrm{C}_{\mathrm{DDE}}$ is the DDE dose equivalent factor for a particular nuclide $\left[\mathrm{rem} \cdot \mathrm{m}^{3} / \mathrm{Ci}-\mathrm{s}\right]$.

The values for $\mathrm{C}_{\mathrm{DDE}}$ can be found in the appendix of Ref [11]. These coefficients are from Federal Guidance Report No. 12, Table 3.1, "Dose due to immersion in a semi-infinite cloud of nuclides". These dose coefficients represent the absorbed dose due to all modes of radiation, mainly gamma and beta radiation, to the body at a tissue depth of $1 \mathrm{~cm}$ weighted over a number of organs.

\subsection{Gamma Dose}

The nuclides which do not escape containment will constitute a source of gamma radiation. There are a number of pathways for the photons inside containment to contribute to the dose at the EAB. These dose pathways were derived by earlier studies, i.e. Refs [9] [10] [11], and have been used in the licensing applications for the MITR. The same dose pathways are thus adopted in the current study.

At first, it is necessary to understand the underlying relations which govern the dose levels. The absorbed dose rate from photons is represented by the general formula below:

$$
\text { Dose }=\mathrm{C}_{\mathrm{D}} \cdot \phi_{\gamma}
$$

where $\quad \mathrm{C}_{\mathrm{D}} \quad$ is the dose conversion factor ( $\mathrm{rem} \cdot \mathrm{cm}^{2} /$ photon), and

$$
\phi_{r} \quad \text { is the photon flux (photons } / \mathrm{cm}^{2}-\mathrm{s} \text { ). }
$$

The dose conversion factor, which represents weighted dose equivalent factors in exposure over an array of organs, is to calculate the TEDE for gamma rays. The NRC regulations allow for the use of the Effective Dose Equivalent (EDE) factors when calculating DDE [13]. The current study adopts the same set of EDE dose conversion factors as Ref [11].

The gamma dose at the EAB includes direct dose through the shielding, as well as scattered dose. The shielding consists of two parts. The sides of the containment building are shielded by concrete and steel. The top of the building is shielded by a steel shell. There will also be radiation dose from the truck lock. The methodology presented in this section was derived by Mull in 1983 [9]. Key equations for calculating gamma flux are summarized in this sub-section.

\section{Direct Gamma Flux}

In order to calculate the direct gamma dose at a given point on the ground outside containment, the containment volume is divided into two parts. The first part $\mathrm{V}_{1}$ is all locations from which gamma rays will reach the target point through the steel dome. The second part $\mathrm{V}_{2}$ is all locations where gamma rays will have to pass through the concrete and steel shadow shield. Volumes $\mathrm{V}_{1}$ and $\mathrm{V}_{2}$ are shown in Figure 3. The values of $\mathrm{V}_{1}$ for $8 \mathrm{~m}$ and $21 \mathrm{~m}$ are $0.01 \mathrm{~V}$ and $0.99 \mathrm{~V}$, respectively. The values of $\mathrm{V}_{2}$ for $8 \mathrm{~m}$ and $21 \mathrm{~m}$ are $0.05 \mathrm{~V}$ and $0.95 \mathrm{~V}$, respectively. 


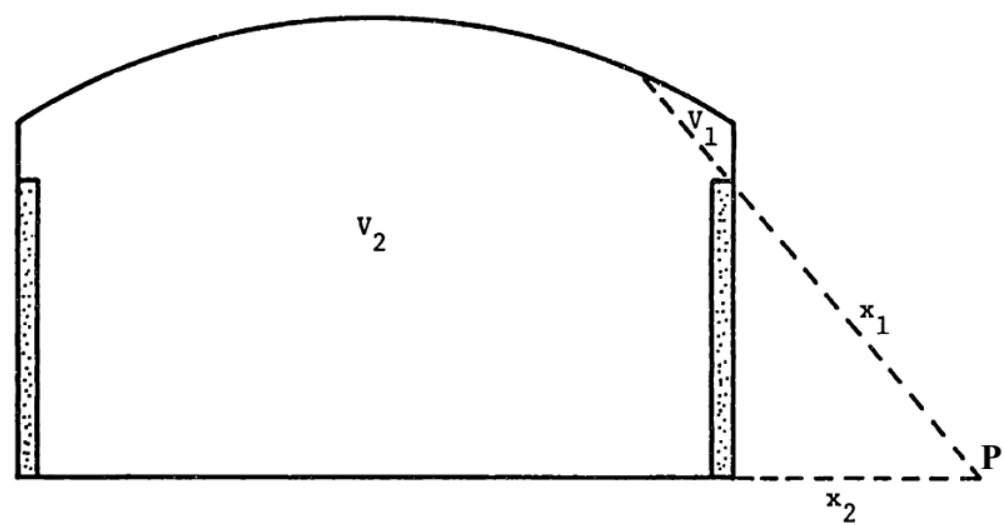

Figure 3. Containment volume division for direct dose calculation.

From the steel shell penetration, the gamma flux is determined approximately as:

$$
\phi_{\gamma}=\frac{2}{3} \mathrm{R}_{1} \mathrm{~S} \mathrm{v}_{1} \mathrm{~B} \cdot\left(\sec \theta_{1}-1\right) \cdot e^{-b 1}
$$

where

$$
\begin{array}{ll}
\mathrm{R} & \text { is the radius of radiation source [m], } \\
\mathrm{S} & \text { is the constant strength of the radiation source [photons } / \mathrm{cm}^{3}-\mathrm{s} \text { ], } \\
\mathrm{B} & \text { is the buildup factor } \\
\theta & \text { is the solid angle to the radiation source [radians], } \\
b & \text { is the number of mean free paths in the steel shield. }
\end{array}
$$

For the shadow shield penetration, the gamma flux is determined approximately as:

$$
\phi_{\gamma}=\frac{\mathrm{R}_{2} \mathrm{~Sv}_{2} \mathrm{~B}}{2 \pi}\left[\mathrm{A} \cdot G\left(k, p, \mu_{s} \mathrm{R}_{2}, b 2^{\prime}\right)+(1-\mathrm{A}) \cdot G\left(k, p, \mu_{s} \mathrm{R}_{2}, b 2^{\prime \prime}\right)\right]
$$

where

$$
\mathrm{G} \text { is the Attenuation Function, }
$$

$k \quad$ is the source height $h$ over the source radius $\mathrm{R}$,

$p \quad$ is the distance to the source $s$ over the source radius $\mathrm{R}$,

$\mu_{s} \quad$ is the linear attenuation coefficient in the source medium $[1 / \mathrm{cm}]$,

A is the energy dependent coefficients of Taylor exposure build-up factor.

It should be noted that the full details of deriving the gamma flux from steel shell penetration and shadow shield penetration according to the MITR dome geometry have not been described in this paper. Only the final solutions, i.e. Eqs. 9 and 10, have been summarized, since they remain unchanged since earlier studies.

\section{Scattered Gamma Flux}

Although the shadow shield is effective at stopping direct radiation, the open top containment design leads to the possibility of gamma radiation escaping upwards and being subsequently scattered back towards the ground through interaction with air or with the steel dome.

Because forward scattering is favored for high energy photons, the effect of sources located at different heights within the containment will vary. Thus the containment volume will be divided into four regions. The first region is the dome portion, $\mathrm{V}_{\mathrm{u}}$, above the shadow shield where the photons only need to be scattered through small angles to reach the exclusion area boundary. The remaining three regions each represent a third 
of the lower portion of containment, $\mathrm{V}_{\mathrm{l}}$, which was subdivided by height. For each volume portion, the source is assumed to be a point source located in the center of the region, based on the assumption of homogeneous mixing of the nuclides within containment. $\mathrm{V}_{\mathrm{u}}$ is $30 \%$ of the total containment volume, $\mathrm{V}_{1}$ contains the remaining $70 \%$. The general relationship between the geometric scattering parameters is shown in Figure 4.

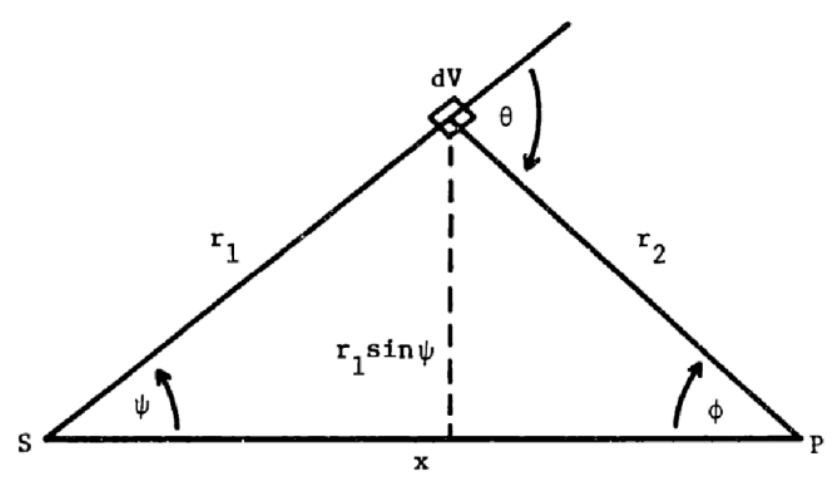

Figure 4. Illustration of general scattering geometric parameters.

The air scattering flux at the point $\mathrm{P}$ from sources for each gamma energy group in the upper volume of containment is:

$$
\phi_{\gamma}=\frac{\mathrm{Su} \cdot N \cdot e^{-b 1}}{4 x} \cdot \int_{\psi 0}^{\pi-\phi 0} d \psi \int_{\phi 0}^{\pi-\psi} d \phi \frac{d \sigma s}{d \Omega}(\theta=\psi+\phi)
$$

Similarly, the air scattering dose from one of the three lower volume sources in containment is:

$$
\phi_{\gamma}=\frac{\mathrm{S}_{1} \cdot N \cdot e^{-b 1}}{12 \pi \cdot x} \cdot \int_{\psi 0}^{\pi-\phi 0} \omega(\psi) d \psi \int_{\phi 0}^{\pi-\psi} d \phi \frac{d \sigma_{s}}{d \Omega}(\theta=\psi+\phi)
$$

where $\quad N \quad$ is the electron density in air $=3.6 \times 10^{20}$ electrons $/ \mathrm{cm}^{3}$,

$x \quad$ is the straight line distance from source $\mathrm{S}$ to point $\mathrm{P}[\mathrm{cm}]$,

$\phi_{0} \quad$ is the initial value of $\phi$ [radians],

$\psi_{0} \quad$ is the initial value of $\psi$ [radians],

$\mathrm{S}_{\mathrm{u}} \quad$ is the source term for upper portion of containment [photons $/ \mathrm{cm}^{3}-\mathrm{s}$ ],

$\mathrm{S}_{1} \quad$ is the source term for lower portion of containment [photons $/ \mathrm{cm}^{3}-\mathrm{s}$ ],

$\omega(\psi)$ is the azimuthal angle relationship for the containment geometry.

The steel scattering flux was calculated using the same source term divisions as the air scattering flux. The flux a point $\mathrm{P}$ due to a single scattering of a photon with the steel dome can be approximated as:

$$
\phi_{\gamma}=\frac{\mathrm{Si}_{\mathrm{i}} \cdot N S T \cdot V S T \cdot e^{-b 1}}{4 \pi \cdot r 1^{2} r 2^{2} \cdot(\psi 2-\psi 1) \cdot(\phi 2-\phi 1)} \cdot \int_{\psi 1}^{\psi 2} d \psi \int_{\phi 1}^{\phi 2} d \phi \frac{d \sigma s}{d \Omega}(\theta=\psi+\phi)
$$

where $\quad \mathrm{S}_{\mathrm{i}} \quad$ is the source strength from given source point [photons $/ \mathrm{cm}^{3}-\mathrm{s}$ ],

$N_{S T} \quad$ is the electron density in steel $=2.19 \times 10^{24}$ electrons $/ \mathrm{cm}^{3}$,

$V_{S T} \quad$ is the total volume of steel in the dome. 
The effect of double scattering was calculated by Mull for the three energies $E=0.4,0.8$, and $2.0 \mathrm{MeV}$ which contributed the most to the total double steel scattering dose. Mull's results indicated that the total steel scattering flux should be increased by a factor of 1.20 at 8 meters and by a factor of 1.02 at 21 meters [9]. The same treatment has also been adopted in Ref [11]. Since the MITR dome geometry remains unchanged, the current study adopts the same conversion factors.

\section{Radiation Penetration through the Truck Lock}

It should be noted that previous studies (Refs. [9] [10] [11]) have proven that the radiation penetration through the truck lock during the two-hour period will add insignificantly to the total dose at the exclusion area boundary from the other modes of release (three orders of magnitude smaller). It thus has been decided to neglect this particular term in this work.

\section{RESULTS}

\subsection{Containment Source Determination}

\section{Source Term of Airborne Release from Containment}

The total radioactivity released from the core for a reference case is shown in Figure 5. The reference case was a 7.35 MW (5\% overpower due to uncertainty in power measurement) LEU core operated for 4200 MWD, with the recommended "19B25" release fractions. Figure 5 demonstrates the behavior of the decay of the total source term over the duration of the accident. The activity remains in containment, the activity released through the stack, and the activity escaped through building leakage are also included. The sum of the three component curves does not equate to the value of the total curve, since the filters in the pressure relief system (through stack) exist and they are particularly effective to iodine absorption.

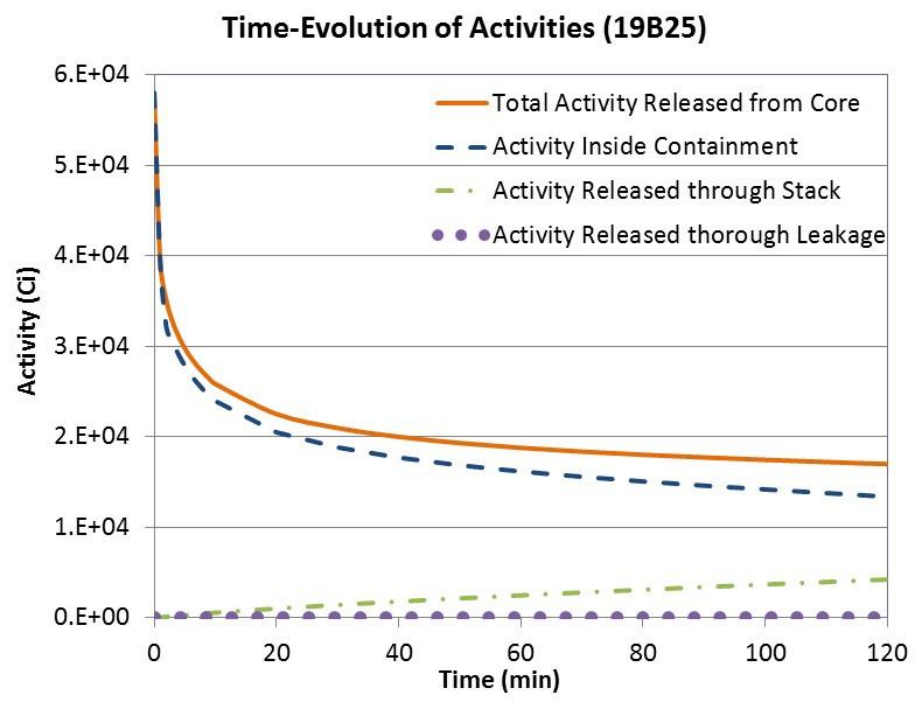

Figure 5. Activity within and released from containment over duration of accident

The nuclide-wise breakdown of activities within and released from containment is presented in Table 7. It includes all the nuclides with important contributions (over $99 \%$ total activities). As can be seen, due to the linear evaporation assumption from primary coolant to containment, the nuclide concentrations (except noble 
gas elements) start from zero at the discharge stage. They will be gradually accumulated in the containment with decay process taken into account. It should be noted that the release terms (via both stack and leakage) neglect further decay process in the ambient for simplicity. Nevertheless, this is a conservative approach in terms of radiation release estimate.

Table 7. Nuclide-wise breakdown of activities within and released from containment

\begin{tabular}{|c|c|c|c|c|c|c|c|}
\hline \multirow{2}{*}{$\begin{array}{c}\text { Major } \\
\text { Nuclides }\end{array}$} & \multicolumn{5}{|c|}{ Activity Inside Containment at Different Time Steps (Ci) } & \multirow{2}{*}{$\begin{array}{l}\text { Integrated } \\
120 \text { min } \\
\text { Release via } \\
\text { Stack }(\mathrm{Ci})\end{array}$} & \multirow{2}{*}{$\begin{array}{c}\text { Integrated } \\
120 \text { min } \\
\text { Release } \\
\text { via Leakage } \\
\text { (Ci) }\end{array}$} \\
\hline & Discharge & $1 \mathrm{~min}$ & $5 \min$ & $30 \mathrm{~min}$ & $120 \mathrm{~min}$ & & \\
\hline $\mathrm{Xe131m}$ & $3.77 \mathrm{E}+01$ & $3.77 \mathrm{E}+01$ & $3.74 \mathrm{E}+01$ & $3.55 \mathrm{E}+01$ & $2.95 \mathrm{E}+01$ & $8.23 \mathrm{E}+00$ & $5.54 \mathrm{E}-02$ \\
\hline Xe133 & $6.99 \mathrm{E}+03$ & $6.99 \mathrm{E}+03$ & $6.94 \mathrm{E}+03$ & $6.59 \mathrm{E}+03$ & $5.46 \mathrm{E}+03$ & $1.53 \mathrm{E}+03$ & $1.03 \mathrm{E}+01$ \\
\hline Xe133m & $8.19 \mathrm{E}+01$ & $8.19 \mathrm{E}+01$ & $8.12 \mathrm{E}+01$ & $7.71 \mathrm{E}+01$ & $6.38 \mathrm{E}+01$ & $1.79 \mathrm{E}+01$ & $1.20 \mathrm{E}-01$ \\
\hline Xe135 & $4.15 \mathrm{E}+03$ & $4.16 \mathrm{E}+03$ & $4.14 \mathrm{E}+03$ & $4.00 \mathrm{E}+03$ & $3.45 \mathrm{E}+03$ & $9.40 \mathrm{E}+02$ & $6.32 \mathrm{E}+00$ \\
\hline $\mathrm{Xe} 135 \mathrm{~m}$ & $9.55 \mathrm{E}+02$ & $9.41 \mathrm{E}+02$ & $8.84 \mathrm{E}+02$ & $6.69 \mathrm{E}+02$ & $4.25 \mathrm{E}+02$ & $1.45 \mathrm{E}+02$ & $9.77 \mathrm{E}-01$ \\
\hline Xe137 & $6.31 \mathrm{E}+03$ & $5.49 \mathrm{E}+03$ & $2.66 \mathrm{E}+03$ & $2.35 \mathrm{E}+01$ & $1.29 \mathrm{E}-06$ & $7.69 \mathrm{E}+01$ & $5.17 \mathrm{E}-01$ \\
\hline Xe138 & $6.25 \mathrm{E}+03$ & $5.96 \mathrm{E}+03$ & $4.85 \mathrm{E}+03$ & $1.32 \mathrm{E}+03$ & $1.10 \mathrm{E}+01$ & $2.51 \mathrm{E}+02$ & $1.69 \mathrm{E}+00$ \\
\hline Kr83m & $4.98 \mathrm{E}+02$ & $4.98 \mathrm{E}+02$ & $4.94 \mathrm{E}+02$ & $4.67 \mathrm{E}+02$ & $3.51 \mathrm{E}+02$ & $1.06 \mathrm{E}+02$ & $7.11 \mathrm{E}-01$ \\
\hline Kr85 & $3.37 \mathrm{E}+01$ & $3.37 \mathrm{E}+01$ & $3.35 \mathrm{E}+01$ & $3.18 \mathrm{E}+01$ & $2.64 \mathrm{E}+01$ & $7.37 \mathrm{E}+00$ & $4.96 \mathrm{E}-02$ \\
\hline $\mathrm{Kr} 85 \mathrm{~m}$ & $1.20 \mathrm{E}+03$ & $1.19 \mathrm{E}+03$ & $1.18 \mathrm{E}+03$ & $1.05 \mathrm{E}+03$ & $6.90 \mathrm{E}+02$ & $2.28 \mathrm{E}+02$ & $1.54 \mathrm{E}+00$ \\
\hline Kr87 & $2.30 \mathrm{E}+03$ & $2.29 \mathrm{E}+03$ & $2.20 \mathrm{E}+03$ & $1.66 \mathrm{E}+03$ & $5.98 \mathrm{E}+02$ & $3.15 \mathrm{E}+02$ & $2.12 \mathrm{E}+00$ \\
\hline Kr88 & $3.09 \mathrm{E}+03$ & $3.08 \mathrm{E}+03$ & $3.01 \mathrm{E}+03$ & $2.58 \mathrm{E}+03$ & $1.47 \mathrm{E}+03$ & $5.40 \mathrm{E}+02$ & $3.63 \mathrm{E}+00$ \\
\hline Kr89 & $3.92 \mathrm{E}+03$ & $3.16 \mathrm{E}+03$ & $1.30 \mathrm{E}+03$ & $4.01 \mathrm{E}+00$ & $6.50 \mathrm{E}-09$ & $3.79 \mathrm{E}+01$ & $2.55 \mathrm{E}-01$ \\
\hline I131 & $0.00 \mathrm{E}+00$ & $8.04 \mathrm{E}-01$ & $4.01 \mathrm{E}+00$ & $2.38 \mathrm{E}+01$ & $9.03 \mathrm{E}+01$ & $1.71 \mathrm{E}-01$ & $2.30 \mathrm{E}-02$ \\
\hline I132 & $0.00 \mathrm{E}+00$ & $1.19 \mathrm{E}+00$ & $5.95 \mathrm{E}+00$ & $3.52 \mathrm{E}+01$ & $1.33 \mathrm{E}+02$ & $2.51 \mathrm{E}-01$ & $3.38 \mathrm{E}-02$ \\
\hline I133 & $0.00 \mathrm{E}+00$ & $1.74 \mathrm{E}+00$ & $8.68 \mathrm{E}+00$ & $5.12 \mathrm{E}+01$ & $1.87 \mathrm{E}+02$ & $3.60 \mathrm{E}-01$ & $4.85 \mathrm{E}-02$ \\
\hline I134 & $0.00 \mathrm{E}+00$ & $2.00 \mathrm{E}+00$ & $9.89 \mathrm{E}+00$ & $5.27 \mathrm{E}+01$ & $9.67 \mathrm{E}+01$ & $2.66 \mathrm{E}-01$ & $3.57 \mathrm{E}-02$ \\
\hline I135 & $0.00 \mathrm{E}+00$ & $1.64 \mathrm{E}+00$ & $8.15 \mathrm{E}+00$ & $4.62 \mathrm{E}+01$ & $1.50 \mathrm{E}+02$ & $3.04 \mathrm{E}-01$ & $4.09 \mathrm{E}-02$ \\
\hline Cs138 & $0.00 \mathrm{E}+00$ & $1.52 \mathrm{E}+00$ & $7.48 \mathrm{E}+00$ & $3.36 \mathrm{E}+01$ & $2.33 \mathrm{E}+01$ & $1.13 \mathrm{E}+00$ & $1.51 \mathrm{E}-02$ \\
\hline Te132 & $0.00 \mathrm{E}+00$ & $2.72 \mathrm{E}-01$ & $1.35 \mathrm{E}+00$ & $7.80 \mathrm{E}+00$ & $2.65 \mathrm{E}+01$ & $1.58 \mathrm{E}+00$ & $2.13 \mathrm{E}-02$ \\
\hline Te134 & $0.00 \mathrm{E}+00$ & $3.86 \mathrm{E}-01$ & $1.80 \mathrm{E}+00$ & $6.87 \mathrm{E}+00$ & $5.19 \mathrm{E}+00$ & $6.98 \mathrm{E}-01$ & 9.39E-03 \\
\hline $\mathrm{Rb} 88$ & $0.00 \mathrm{E}+00$ & 7.03E-01 & $3.49 \mathrm{E}+00$ & $1.92 \mathrm{E}+01$ & $4.71 \mathrm{E}+01$ & $3.29 \mathrm{E}+00$ & $4.43 \mathrm{E}-02$ \\
\hline Rb89 & $0.00 \mathrm{E}+00$ & $9.26 \mathrm{E}-01$ & $4.23 \mathrm{E}+00$ & $8.45 \mathrm{E}+00$ & 4.29E-01 & $4.60 \mathrm{E}-01$ & $6.19 \mathrm{E}-03$ \\
\hline Br84 & $0.00 \mathrm{E}+00$ & $2.18 \mathrm{E}-01$ & $1.04 \mathrm{E}+00$ & $3.61 \mathrm{E}+00$ & $1.69 \mathrm{E}+00$ & $3.11 \mathrm{E}-01$ & $4.18 \mathrm{E}-03$ \\
\hline Sum & $3.58 \mathrm{E}+04$ & $3.39 \mathrm{E}+04$ & $2.79 \mathrm{E}+04$ & $1.88 \mathrm{E}+04$ & $1.33 \mathrm{E}+04$ & $4.21 \mathrm{E}+03$ & $2.86 \mathrm{E}+01$ \\
\hline
\end{tabular}




\section{Source Term Contributed to Gamma Dose}

The total gamma emissions at each energy group from 5 melted plates of 7 MW 19B25 LEU fuel (irradiated for 4200 MWD) are presented in Table 8. Both integral and volumetric source terms are included. This table with multiple intermediate time steps is intended to demonstrate how the magnitude of the gamma source decreases over time.

Table 8. Gamma Source Term as Function of Time for 7MW 19B25 LEU Fuel

\begin{tabular}{|c|c|c|c|c|c|c|c|}
\hline \multirow{2}{*}{$\begin{array}{c}\text { Midpoint } \\
\text { Gamma } \\
\text { Energy } \\
\text { in a Bin } \\
(\mathrm{MeV})\end{array}$} & \multicolumn{6}{|c|}{ Gamma Source Term for Entire Containment Volume (photons/s) } & \multirow{2}{*}{\begin{tabular}{|c}
$\begin{array}{c}\text { Volumetric Source } \\
\text { (photons/cm }\end{array} \mathrm{cm}^{3}$ ) \\
Average
\end{tabular}} \\
\hline & $10 \mathrm{~min}$ & $30 \mathrm{~min}$ & $60 \min$ & $90 \mathrm{~min}$ & $120 \mathrm{~min}$ & Average & \\
\hline 0.03 & $1.87 \mathrm{E}+14$ & $1.60 \mathrm{E}+14$ & $1.42 \mathrm{E}+14$ & $1.31 \mathrm{E}+14$ & $1.21 \mathrm{E}+14$ & $1.44 \mathrm{E}+14$ & 30548 \\
\hline 0.04 & $3.80 \mathrm{E}+13$ & $2.76 \mathrm{E}+13$ & $2.26 \mathrm{E}+13$ & $1.98 \mathrm{E}+13$ & $1.77 \mathrm{E}+13$ & $2.38 \mathrm{E}+13$ & 5031 \\
\hline 0.05 & $2.56 \mathrm{E}+13$ & $1.58 \mathrm{E}+13$ & $1.16 \mathrm{E}+13$ & $9.52 \mathrm{E}+12$ & $8.10 \mathrm{E}+12$ & $1.29 \mathrm{E}+13$ & 2724 \\
\hline 0.0625 & $2.67 \mathrm{E}+13$ & $1.64 \mathrm{E}+13$ & $1.19 \mathrm{E}+13$ & $9.68 \mathrm{E}+12$ & $8.17 \mathrm{E}+12$ & $1.33 \mathrm{E}+13$ & 2803 \\
\hline 0.08 & $1.25 \mathrm{E}+14$ & $1.11 \mathrm{E}+14$ & $1.01 \mathrm{E}+14$ & $9.39 \mathrm{E}+13$ & $8.74 \mathrm{E}+13$ & $1.02 \mathrm{E}+14$ & 21540 \\
\hline 0.1075 & $3.20 \mathrm{E}+13$ & $1.94 \mathrm{E}+13$ & $1.40 \mathrm{E}+13$ & $1.13 \mathrm{E}+13$ & $9.41 \mathrm{E}+12$ & $1.56 \mathrm{E}+13$ & 3296 \\
\hline 0.15 & $6.53 \mathrm{E}+13$ & $4.89 \mathrm{E}+13$ & $3.86 \mathrm{E}+13$ & $3.25 \mathrm{E}+13$ & $2.79 \mathrm{E}+13$ & $4.04 \mathrm{E}+13$ & 8539 \\
\hline 0.2125 & $1.31 \mathrm{E}+14$ & $1.15 \mathrm{E}+14$ & $1.03 \mathrm{E}+14$ & $9.48 \mathrm{E}+13$ & $8.76 \mathrm{E}+13$ & $1.04 \mathrm{E}+14$ & 22013 \\
\hline 0.3 & $1.22 \mathrm{E}+14$ & $8.71 \mathrm{E}+13$ & $6.97 \mathrm{E}+13$ & $6.26 \mathrm{E}+13$ & $5.80 \mathrm{E}+13$ & $7.53 \mathrm{E}+13$ & 15930 \\
\hline 0.4 & $9.90 \mathrm{E}+13$ & $5.82 \mathrm{E}+13$ & $3.50 \mathrm{E}+13$ & $2.52 \mathrm{E}+13$ & $1.99 \mathrm{E}+13$ & $4.19 \mathrm{E}+13$ & 8856 \\
\hline 0.5 & $4.99 \mathrm{E}+13$ & $2.55 \mathrm{E}+13$ & $1.97 \mathrm{E}+13$ & $1.88 \mathrm{E}+13$ & $1.89 \mathrm{E}+13$ & $2.36 \mathrm{E}+13$ & 4994 \\
\hline 0.625 & $1.33 \mathrm{E}+13$ & $1.13 \mathrm{E}+13$ & $1.15 \mathrm{E}+13$ & $1.22 \mathrm{E}+13$ & $1.30 \mathrm{E}+13$ & $1.20 \mathrm{E}+13$ & 2541 \\
\hline 0.8 & $3.56 \mathrm{E}+13$ & $3.08 \mathrm{E}+13$ & $2.83 \mathrm{E}+13$ & $2.65 \mathrm{E}+13$ & $2.46 \mathrm{E}+13$ & $2.85 \mathrm{E}+13$ & 6036 \\
\hline 1.075 & $3.16 \mathrm{E}+13$ & $1.93 \mathrm{E}+13$ & $1.40 \mathrm{E}+13$ & $1.25 \mathrm{E}+13$ & $1.18 \mathrm{E}+13$ & $1.63 \mathrm{E}+13$ & 3436 \\
\hline 1.5 & $6.48 \mathrm{E}+13$ & $3.61 \mathrm{E}+13$ & $2.20 \mathrm{E}+13$ & $1.73 \mathrm{E}+13$ & $1.49 \mathrm{E}+13$ & $2.72 \mathrm{E}+13$ & 5756 \\
\hline 2.125 & $1.33 \mathrm{E}+14$ & $9.14 \mathrm{E}+13$ & $6.52 \mathrm{E}+13$ & $5.21 \mathrm{E}+13$ & $4.30 \mathrm{E}+13$ & $7.12 \mathrm{E}+13$ & 15053 \\
\hline 3 & $1.41 \mathrm{E}+13$ & $1.04 \mathrm{E}+13$ & $7.13 \mathrm{E}+12$ & $5.17 \mathrm{E}+12$ & $3.83 \mathrm{E}+12$ & $7.56 \mathrm{E}+12$ & 1598 \\
\hline 4 & $7.29 \mathrm{E}+10$ & $5.81 \mathrm{E}+10$ & $4.67 \mathrm{E}+10$ & $3.76 \mathrm{E}+10$ & $3.03 \mathrm{E}+10$ & $4.70 \mathrm{E}+10$ & 10 \\
\hline Total & $1.19 \mathrm{E}+15$ & $8.84 \mathrm{E}+14$ & $7.18 \mathrm{E}+14$ & $6.34 \mathrm{E}+14$ & $5.75 \mathrm{E}+14$ & $7.60 \mathrm{E}+14$ & 160710 \\
\hline
\end{tabular}

\subsection{Atmospheric Dose}

Figure 6 shows the concentration values as a function of distance from the stack for all atmospheric stability conditions. Stable atmospheric conditions indicate that the plume will be spread over a larger range, where unstable conditions lead to more pollutant being deposited over a smaller range. Reduction of fission product inventory due to ground deposition and precipitation scavenging was conservatively neglected. 


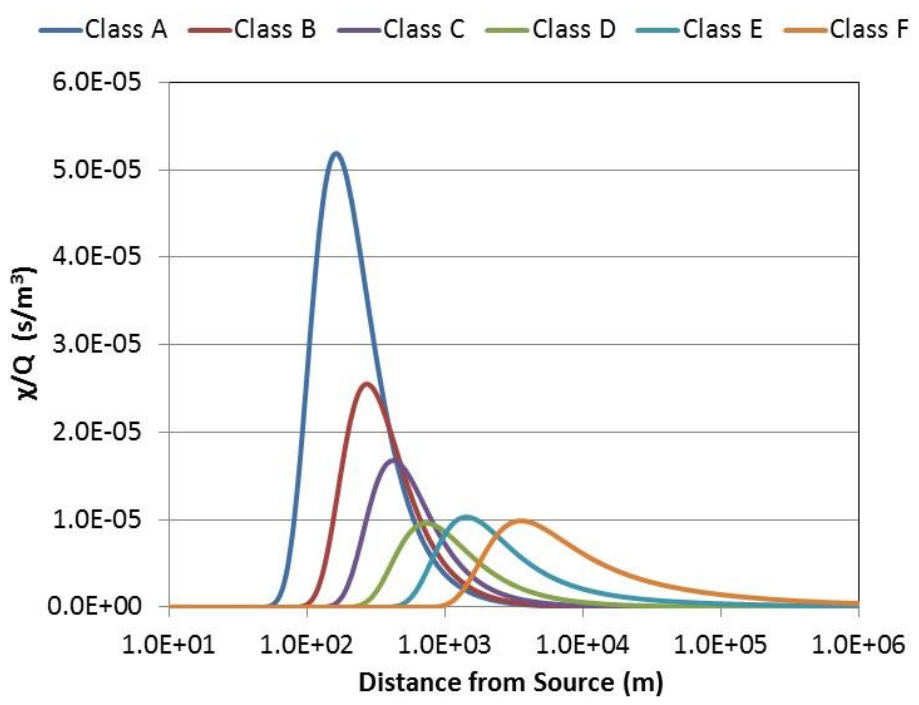

Figure 6. $\chi / Q$ distributions with different atmospheric stability conditions for stack release.

Table 9 shows the two-hour dose from stack release at maximum concentration distances. Class D is the most probable stability condition accounting for $73.94 \%$ of total events. The corresponding two-hour TEDE dose is as low as $3.7 \mathrm{mrem}$. It should be noted that the peaking location (i.e. the maximum concentration distance) is $731 \mathrm{~m}$ away from the MITR containment. On the other hand, the values of $\chi / Q$ within approx. $50 \mathrm{~m}$ from the source are at very low level for all Classes. Thus, the dose contribution from stack release will not be added to the dose estimations at the EABs, which are $8 \mathrm{~m}$ and $21 \mathrm{~m}$ away, respectively.

Table 9. Two-hour dose from stack release at maximum concentration distances

\begin{tabular}{|c|c|c|c|c|c|c|}
\hline $\begin{array}{c}\text { Atmospheric } \\
\begin{array}{c}\text { Stability } \\
\text { Class }\end{array}\end{array}$ & $\begin{array}{c}\text { Occurrence } \\
\text { Frequency } \\
(\%)\end{array}$ & $\begin{array}{c}\text { Maximum } \\
\text { Concentration } \\
\text { Distance }(\mathrm{m})\end{array}$ & $\begin{array}{c}\text { Maximum } \\
\chi / \mathrm{Q} \\
\left(\mathrm{s} / \mathrm{m}^{3}\right)\end{array}$ & $\begin{array}{c}\text { Two-hour } \\
\text { CEDE Dose } \\
(\mathrm{rem})\end{array}$ & $\begin{array}{c}\text { Two-hour } \\
\text { DDE Dose } \\
(\mathrm{rem})\end{array}$ & $\begin{array}{c}\text { Two-hour } \\
\text { TEDE Dose } \\
(\mathrm{rem})\end{array}$ \\
\hline A & 0.08 & 163 & $5.19 \mathrm{E}-05$ & $4.47 \mathrm{E}-04$ & $1.94 \mathrm{E}-02$ & $1.99 \mathrm{E}-02$ \\
\hline B & 1.83 & 272 & $2.56 \mathrm{E}-05$ & $2.20 \mathrm{E}-04$ & $9.57 \mathrm{E}-03$ & $9.79 \mathrm{E}-03$ \\
\hline C & 8.30 & 421 & $1.67 \mathrm{E}-05$ & $1.44 \mathrm{E}-04$ & $6.25 \mathrm{E}-03$ & $6.40 \mathrm{E}-03$ \\
\hline D & $\mathbf{7 3 . 9 4}$ & $\mathbf{7 3 1}$ & $\mathbf{9 . 6 0 E}-06$ & $\mathbf{8 . 2 7 E - 0 5}$ & $\mathbf{3 . 6 0 E}-03$ & $\mathbf{3 . 6 8 E}-03$ \\
\hline E & 12.03 & 1433 & $1.03 \mathrm{E}-05$ & $8.88 \mathrm{E}-05$ & $3.86 \mathrm{E}-03$ & $3.95 \mathrm{E}-03$ \\
\hline F & 3.81 & 3553 & $9.90 \mathrm{E}-06$ & $8.53 \mathrm{E}-05$ & $3.71 \mathrm{E}-03$ & $3.79 \mathrm{E}-03$ \\
\hline
\end{tabular}

$\chi$ : Ground level concentration $\left(\mathrm{Ci} / \mathrm{m}^{3}\right)$

$Q$ : Pollutant exit rate from containment $(\mathrm{Ci} / \mathrm{s})$

CEDE: Committed Effective Dose Equivalent (from inhalation)

DDE: Deep Dose Equivalent (from immersion in semi-infinite cloud)

TEDE: Total Effective Dose Equivalent (CEDE + DDE)

The $\chi / Q$ curves of atmospheric dispersion from containment leakage considering full wake effect (i.e. according to Eq. 5) is shown in Figure 7. As can be seen, only Class A stability yields higher $\chi / Q$ values than Class F stability. Class A has an occurrence frequency of less than $0.1 \%$, thus Class F stability would give a conservative prediction with a frequency greater than $99.9 \%$. 


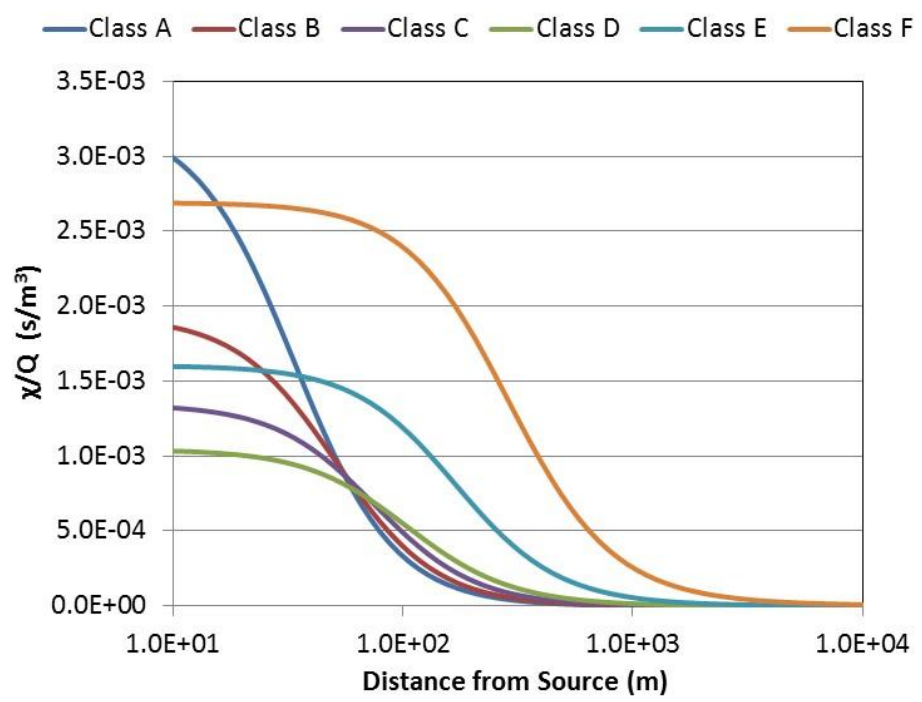

Figure 7. $\chi / Q$ distributions with different atmospheric stability conditions for containment leakage release considering full wake effect.

Table 10 shows the two-hour dose from containment leakage at the MITR EABs. As mentioned earlier, Pasquill Stability Class F (a stable class) is adopted for the calculations. In addition, full wake effect treatment is used. This methodology, which was used for the previous dose calculations in the MITR SAR [3], is again used in this work. As can be seen, the two-hour TEDE doses from containment leakage of 8.2 mrem and 8.1 mrem at Back Fence $(8 \mathrm{~m})$ and Front Fence $(21 \mathrm{~m})$, respectively. These dose contributions will be taken into account in Section 3.4 for the total radiation release estimation.

Table 10. Two-hour dose from containment leakage at two MITR exclusion area boundaries (Class $F$ is adopted and full wake effect treatment is used.)

\begin{tabular}{|c|c|c|c|c|}
\hline MITR Boundaries & $\begin{array}{c}\chi / \mathrm{Q} \\
\left(\mathrm{s} / \mathrm{m}^{3}\right)\end{array}$ & $\begin{array}{c}\text { Two-hour } \\
\text { CEDE Dose } \\
(\mathrm{rem})\end{array}$ & $\begin{array}{c}\text { Two-hour } \\
\text { DDE Dose } \\
(\mathrm{rem})\end{array}$ & $\begin{array}{c}\text { Two-hour } \\
\text { TEDE Dose } \\
(\mathrm{rem})\end{array}$ \\
\hline Back Fence $(8 \mathrm{~m})$ & $2.69 \mathrm{E}-03$ & $1.25 \mathrm{E}-03$ & $6.93 \mathrm{E}-03$ & $8.18 \mathrm{E}-03$ \\
\hline Front Fence $(21 \mathrm{~m})$ & $2.68 \mathrm{E}-03$ & $1.24 \mathrm{E}-03$ & $6.90 \mathrm{E}-03$ & $8.14 \mathrm{E}-03$ \\
\hline
\end{tabular}

\subsection{Gamma Dose}

The four gamma DDE components, a) direct gamma flux through steel dome penetration, b) direct gamma flux through shadow shield penetration, c) scattered gamma flux after interaction with air, and d) scattered gamma flux after interaction with steel dome, are further analyzed in this sub-section. The contribution from each gamma energy group and the photon flux at the EABs are presented in Tables $11-14$. These are to provide complete information of the MHA estimated doses for the 19B25 LEU fueled MITR core. As mentioned in Section 2.5, the total steel scattering flux has been increased by a factor of 1.20 at 8 meters and by a factor of 1.02 at 21 meters, in order to take into account the effect of double scattering. 
Table 11. Two-hour DDE Gamma Dose from Direct Steel Shell Penetration

\begin{tabular}{|c|c|c|c|c|c|}
\hline \multirow{2}{*}{$\begin{array}{c}\text { Gamma Energy } \\
(\mathrm{MeV})\end{array}$} & \multirow{2}{*}{$\begin{array}{c}\mathrm{C}_{\mathrm{D}, \mathrm{EDE}} \\
\left(\mathrm{rem} \cdot \mathrm{cm}^{2} \cdot \mathrm{s}\right)\end{array}$} & \multicolumn{2}{|c|}{$8 \mathrm{~m}$} & \multicolumn{2}{|c|}{$21 \mathrm{~m}$} \\
\hline & & $\begin{array}{c}\phi_{\gamma} \\
\left(\gamma / \mathrm{cm}^{2} / \mathrm{s}\right)\end{array}$ & $\begin{array}{l}\text { Dose } \\
\text { (rem) }\end{array}$ & $\begin{array}{c}\phi_{\gamma} \\
\left(\gamma / \mathrm{cm}^{2} / \mathrm{s}\right)\end{array}$ & $\begin{array}{l}\text { Dose } \\
\text { (rem) }\end{array}$ \\
\hline 0.03 & $9.72 \mathrm{E}-08$ & - & - & - & - \\
\hline 0.04 & $1.15 \mathrm{E}-07$ & - & - & - & - \\
\hline 0.05 & $1.26 \mathrm{E}-07$ & - & - & - & - \\
\hline 0.0625 & $1.48 \mathrm{E}-07$ & - & - & - & - \\
\hline 0.08 & $1.73 \mathrm{E}-07$ & - & - & - & - \\
\hline 0.1075 & $2.23 \mathrm{E}-07$ & 17.7 & $3.95 \mathrm{E}-06$ & 136.4 & $3.04 \mathrm{E}-05$ \\
\hline 0.15 & $3.06 \mathrm{E}-07$ & 112.2 & $3.43 \mathrm{E}-05$ & 865.4 & $2.65 \mathrm{E}-04$ \\
\hline 0.2125 & $4.68 \mathrm{E}-07$ & 390.5 & $1.83 \mathrm{E}-04$ & 3012.5 & $1.41 \mathrm{E}-03$ \\
\hline 0.3 & $6.84 \mathrm{E}-07$ & 284.6 & $1.95 \mathrm{E}-04$ & 2195.1 & $1.50 \mathrm{E}-03$ \\
\hline 0.4 & $9.36 \mathrm{E}-07$ & 155.3 & $1.45 \mathrm{E}-04$ & 1198.2 & $1.12 \mathrm{E}-03$ \\
\hline 0.5 & 1.19E-06 & 108.3 & $1.29 \mathrm{E}-04$ & 835.8 & $9.93 \mathrm{E}-04$ \\
\hline 0.625 & $1.48 \mathrm{E}-06$ & 55.8 & $8.24 \mathrm{E}-05$ & 430.4 & $6.35 \mathrm{E}-04$ \\
\hline 0.8 & $1.87 \mathrm{E}-06$ & 134.0 & $2.51 \mathrm{E}-04$ & 1034.0 & $1.94 \mathrm{E}-03$ \\
\hline 1.075 & $2.45 \mathrm{E}-06$ & 76.4 & $1.87 \mathrm{E}-04$ & 589.4 & $1.44 \mathrm{E}-03$ \\
\hline 1.5 & $3.24 \mathrm{E}-06$ & 127.9 & $4.14 \mathrm{E}-04$ & 986.7 & $3.20 \mathrm{E}-03$ \\
\hline 2.125 & $4.32 \mathrm{E}-06$ & 330.1 & $1.43 \mathrm{E}-03$ & 2546.2 & $1.10 \mathrm{E}-02$ \\
\hline 3 & $5.76 \mathrm{E}-06$ & 34.5 & $1.99 \mathrm{E}-04$ & 266.0 & $1.53 \mathrm{E}-03$ \\
\hline 4 & $7.20 \mathrm{E}-06$ & 0.2 & $1.53 \mathrm{E}-06$ & 1.6 & $1.18 \mathrm{E}-05$ \\
\hline Total & - & - & 0.0033 & - & 0.0251 \\
\hline
\end{tabular}

Table 12. Two-hour DDE Gamma Dose from Direct Shadow Shield Penetration

\begin{tabular}{|c|c|c|c|c|c|}
\hline \multirow{2}{*}{$\begin{array}{c}\text { Gamma Energy } \\
(\mathrm{MeV})\end{array}$} & \multirow{2}{*}{$\begin{array}{c}\mathrm{C}_{\mathrm{D}, \mathrm{EDE}} \\
\left(\mathrm{rem} \cdot \mathrm{cm}^{2} \cdot \mathrm{s}\right)\end{array}$} & $\begin{array}{c}\phi_{\gamma} \\
\left(\gamma / \mathrm{cm}^{2} / \mathrm{s}\right)\end{array}$ & $\begin{array}{c}\text { Dose } \\
(\mathrm{rem})\end{array}$ & $\begin{array}{c}\phi_{\gamma} \\
\left(\gamma / \mathrm{cm}^{2} / \mathrm{s}\right)\end{array}$ & $\begin{array}{c}\text { Dose } \\
(\mathrm{rem})\end{array}$ \\
\hline 0.03 & $9.72 \mathrm{E}-08$ & - & - & - & - \\
\hline 0.04 & $1.15 \mathrm{E}-07$ & - & - & - & - \\
\hline 0.05 & $1.26 \mathrm{E}-07$ & - & - & - & - \\
\hline 0.0625 & $1.48 \mathrm{E}-07$ & - & - & - & - \\
\hline 0.08 & $1.73 \mathrm{E}-07$ & - & - & - & - \\
\hline 0.1075 & $2.23 \mathrm{E}-07$ & 0.0 & - & 0.0 & - \\
\hline 0.15 & $3.06 \mathrm{E}-07$ & 0.0 & - & 0.0 & - \\
\hline 0.2125 & $4.68 \mathrm{E}-07$ & 0.7 & $3.49 \mathrm{E}-07$ & 0.5 & $2.53 \mathrm{E}-07$ \\
\hline 0.3 & $6.84 \mathrm{E}-07$ & 6.2 & $4.23 \mathrm{E}-06$ & 4.3 & $2.94 \mathrm{E}-06$ \\
\hline 0.4 & $9.36 \mathrm{E}-07$ & 13.8 & $1.29 \mathrm{E}-05$ & 9.5 & $8.85 \mathrm{E}-06$ \\
\hline 0.5 & $1.19 \mathrm{E}-06$ & 20.8 & $2.47 \mathrm{E}-05$ & 143.4 & $1.70 \mathrm{E}-04$ \\
\hline 0.625 & $1.48 \mathrm{E}-06$ & 17.0 & $2.51 \mathrm{E}-05$ & 9.8 & $1.44 \mathrm{E}-05$ \\
\hline 0.8 & $1.87 \mathrm{E}-06$ & 129.1 & $2.42 \mathrm{E}-04$ & 85.8 & $1.61 \mathrm{E}-04$ \\
\hline 1.075 & $2.45 \mathrm{E}-06$ & 206.9 & $5.06 \mathrm{E}-04$ & 77.6 & $1.90 \mathrm{E}-04$ \\
\hline 1.5 & $3.24 \mathrm{E}-06$ & 1261.3 & $4.09 \mathrm{E}-03$ & 592.8 & $1.92 \mathrm{E}-03$ \\
\hline 2.125 & $4.32 \mathrm{E}-06$ & 6883.7 & $2.97 \mathrm{E}-02$ & 3325.3 & $1.44 \mathrm{E}-02$ \\
\hline 3 & $5.76 \mathrm{E}-06$ & 2275.7 & $1.31 \mathrm{E}-02$ & 979.2 & $5.64 \mathrm{E}-03$ \\
\hline 4 & $7.20 \mathrm{E}-06$ & 17.1 & $1.23 \mathrm{E}-04$ & 9.2 & $6.63 \mathrm{E}-05$ \\
\hline Total & - & - & 0.0479 & - & 0.0225 \\
\hline
\end{tabular}


Table 13. Two-hour DDE Gamma Dose from Air Scattering

\begin{tabular}{|c|c|c|c|c|c|c|c|c|}
\hline \multirow{3}{*}{$\begin{array}{l}\text { Gamma } \\
\text { Energy } \\
(\mathrm{MeV})\end{array}$} & \multicolumn{8}{|c|}{$8 \mathrm{~m}$} \\
\hline & \multicolumn{2}{|c|}{ Upper Sources } & \multicolumn{2}{|c|}{ Lower Point 1} & \multicolumn{2}{|c|}{ Lower Point 2} & \multicolumn{2}{|c|}{ Lower Point 3} \\
\hline & $\begin{array}{c}\phi_{\gamma} \\
\left(\gamma / \mathrm{cm}^{2} / \mathrm{s}\right)\end{array}$ & $\begin{array}{l}\text { Dose } \\
\text { (rem) }\end{array}$ & $\begin{array}{c}\phi_{\gamma} \\
\left(\gamma / \mathrm{cm}^{2} / \mathrm{s}\right)\end{array}$ & $\begin{array}{l}\text { Dose } \\
\text { (rem) }\end{array}$ & $\begin{array}{c}\phi_{\gamma} \\
\left(\gamma / \mathrm{cm}^{2} / \mathrm{s}\right)\end{array}$ & $\begin{array}{l}\text { Dose } \\
\text { (rem) }\end{array}$ & $\begin{array}{c}\phi_{\gamma} \\
\left(\gamma / \mathrm{cm}^{2} / \mathrm{s}\right)\end{array}$ & $\begin{array}{l}\text { Dose } \\
\text { (rem) }\end{array}$ \\
\hline 0.03 & 0.0 & - & 0.0 & - & 0.0 & - & 0.0 & - \\
\hline 0.04 & 0.0 & - & 0.0 & - & 0.0 & - & 0.0 & - \\
\hline 0.05 & 0.0 & - & 0.0 & - & 0.0 & - & 0.0 & - \\
\hline 0.0625 & 5.0 & $7.41 \mathrm{E}-07$ & 2.1 & $3.13 \mathrm{E}-07$ & 1.9 & $2.86 \mathrm{E}-07$ & 1.9 & $2.58 \mathrm{E}-07$ \\
\hline 0.08 & 2214.4 & $3.83 \mathrm{E}-04$ & 928.1 & $1.60 \mathrm{E}-04$ & 845.2 & $1.46 \mathrm{E}-04$ & 845.2 & $1.31 \mathrm{E}-04$ \\
\hline 0.1075 & 1275.4 & $2.85 \mathrm{E}-04$ & 529.2 & $1.18 \mathrm{E}-04$ & 479.0 & $1.07 \mathrm{E}-04$ & 479.0 & $9.56 \mathrm{E}-05$ \\
\hline 0.15 & 8155.4 & $2.50 \mathrm{E}-03$ & 3335.7 & $1.02 \mathrm{E}-03$ & 2993.3 & $9.16 \mathrm{E}-04$ & 2993.3 & $8.14 \mathrm{E}-04$ \\
\hline 0.2125 & 21600.3 & $1.01 \mathrm{E}-02$ & 8669.1 & $4.06 \mathrm{E}-03$ & 7693.5 & $3.60 \mathrm{E}-03$ & 7693.5 & $3.17 \mathrm{E}-03$ \\
\hline 0.3 & 14237.4 & $9.74 \mathrm{E}-03$ & 5585.6 & $3.82 \mathrm{E}-03$ & 4893.2 & $3.35 \mathrm{E}-03$ & 4893.2 & $2.92 \mathrm{E}-03$ \\
\hline 0.4 & 6478.7 & $6.06 \mathrm{E}-03$ & 2487.2 & $2.33 \mathrm{E}-03$ & 2152.6 & $2.01 \mathrm{E}-03$ & 2152.6 & $1.74 \mathrm{E}-03$ \\
\hline 0.5 & 3025.8 & $3.59 \mathrm{E}-03$ & 1140.6 & $1.36 \mathrm{E}-03$ & 977.3 & $1.16 \mathrm{E}-03$ & 977.3 & $9.97 \mathrm{E}-04$ \\
\hline 0.625 & 1233.2 & $1.82 \mathrm{E}-03$ & 456.0 & $6.73 \mathrm{E}-04$ & 386.6 & $5.71 \mathrm{E}-04$ & 386.6 & $4.86 \mathrm{E}-04$ \\
\hline 0.8 & 2291.9 & $4.29 \mathrm{E}-03$ & 829.1 & $1.55 \mathrm{E}-03$ & 694.4 & $1.30 \mathrm{E}-03$ & 694.4 & $1.10 \mathrm{E}-03$ \\
\hline 1.075 & 918.6 & $2.25 \mathrm{E}-03$ & 323.4 & $7.92 \mathrm{E}-04$ & 266.8 & $6.53 \mathrm{E}-04$ & 266.8 & $5.46 \mathrm{E}-04$ \\
\hline 1.5 & 1037.4 & $3.36 \mathrm{E}-03$ & 354.1 & $1.15 \mathrm{E}-03$ & 287.3 & $9.31 \mathrm{E}-04$ & 287.3 & $7.69 \mathrm{E}-04$ \\
\hline 2.125 & 1670.9 & $7.22 \mathrm{E}-03$ & 552.4 & $2.39 \mathrm{E}-03$ & 440.6 & $1.90 \mathrm{E}-03$ & 440.6 & $1.55 \mathrm{E}-03$ \\
\hline 3 & 107.2 & $6.17 \mathrm{E}-04$ & 34.4 & $1.98 \mathrm{E}-04$ & 27.0 & $1.55 \mathrm{E}-04$ & 27.0 & $1.26 \mathrm{E}-04$ \\
\hline 4 & 0.4 & $3.03 \mathrm{E}-06$ & 0.1 & $9.50 \mathrm{E}-07$ & 0.1 & $7.38 \mathrm{E}-07$ & 0.1 & $5.93 \mathrm{E}-07$ \\
\hline Total & - & 0.0522 & - & 0.0196 & - & 0.0168 & - & 0.0145 \\
\hline
\end{tabular}

\begin{tabular}{|c|c|c|c|c|c|c|c|c|}
\hline \multirow{3}{*}{$\begin{array}{l}\text { Gamma } \\
\text { Energy } \\
(\mathrm{MeV})\end{array}$} & \multicolumn{8}{|c|}{$21 \mathrm{~m}$} \\
\hline & \multicolumn{2}{|c|}{ Upper Sources } & \multicolumn{2}{|c|}{ Lower Point 1} & \multicolumn{2}{|c|}{ Lower Point 2} & \multicolumn{2}{|c|}{ Lower Point 3} \\
\hline & $\begin{array}{c}\phi_{\gamma} \\
\left(\gamma / \mathrm{cm}^{2} / \mathrm{s}\right)\end{array}$ & $\begin{array}{l}\text { Dose } \\
\text { (rem) }\end{array}$ & $\begin{array}{c}\phi_{\gamma} \\
\left(\gamma / \mathrm{cm}^{2} / \mathrm{s}\right)\end{array}$ & $\begin{array}{l}\text { Dose } \\
\text { (rem) }\end{array}$ & $\begin{array}{c}\phi_{\gamma} \\
\left(\gamma / \mathrm{cm}^{2} / \mathrm{s}\right)\end{array}$ & $\begin{array}{l}\text { Dose } \\
\text { (rem) }\end{array}$ & $\begin{array}{c}\phi_{\gamma} \\
\left(\gamma / \mathrm{cm}^{2} / \mathrm{s}\right)\end{array}$ & $\begin{array}{l}\text { Dose } \\
\text { (rem) }\end{array}$ \\
\hline 0.03 & 0.0 & - & 0.0 & - & 0.0 & - & 0.0 & - \\
\hline 0.04 & 0.0 & - & 0.0 & - & 0.0 & - & 0.0 & - \\
\hline 0.05 & 0.0 & - & 0.0 & - & 0.0 & - & 0.0 & - \\
\hline 0.0625 & 4.8 & $7.04 \mathrm{E}-07$ & 1.9 & $2.87 \mathrm{E}-07$ & 1.8 & $2.62 \mathrm{E}-07$ & 1.7 & $2.46 \mathrm{E}-07$ \\
\hline 0.08 & 2134.8 & $3.69 \mathrm{E}-04$ & 860.9 & $1.49 \mathrm{E}-04$ & 780.9 & $1.35 \mathrm{E}-04$ & 729.9 & $1.26 \mathrm{E}-04$ \\
\hline 0.1075 & 1253.0 & $2.80 \mathrm{E}-04$ & 498.2 & $1.11 \mathrm{E}-04$ & 447.7 & $9.99 \mathrm{E}-05$ & 415.5 & $9.27 \mathrm{E}-05$ \\
\hline 0.15 & 8239.8 & $2.52 \mathrm{E}-03$ & 3207.5 & $9.81 \mathrm{E}-04$ & 2843.7 & $8.70 \mathrm{E}-04$ & 2612.9 & $8.00 \mathrm{E}-04$ \\
\hline 0.2125 & 22679.0 & $1.06 \mathrm{E}-02$ & 8573.9 & $4.01 \mathrm{E}-03$ & 7464.3 & $3.49 \mathrm{E}-03$ & 6770.6 & $3.17 \mathrm{E}-03$ \\
\hline 0.3 & 15693.3 & $1.07 \mathrm{E}-02$ & 5715.2 & $3.91 \mathrm{E}-03$ & 4866.1 & $3.33 \mathrm{E}-03$ & 4347.5 & $2.97 \mathrm{E}-03$ \\
\hline 0.4 & 7501.6 & $7.02 \mathrm{E}-03$ & 2629.2 & $2.46 \mathrm{E}-03$ & 2190.8 & $2.05 \mathrm{E}-03$ & 1929.8 & $1.81 \mathrm{E}-03$ \\
\hline 0.5 & 3660.3 & $4.35 \mathrm{E}-03$ & 1239.5 & $1.47 \mathrm{E}-03$ & 1014.0 & $1.20 \mathrm{E}-03$ & 882.7 & $1.05 \mathrm{E}-03$ \\
\hline 0.625 & 1565.9 & $2.31 \mathrm{E}-03$ & 510.2 & $7.53 \mathrm{E}-04$ & 409.3 & $6.04 \mathrm{E}-04$ & 352.0 & $5.20 \mathrm{E}-04$ \\
\hline 0.8 & 3087.7 & $5.78 \mathrm{E}-03$ & 959.2 & $1.80 \mathrm{E}-03$ & 752.3 & $1.41 \mathrm{E}-03$ & 638.0 & $1.19 \mathrm{E}-03$ \\
\hline 1.075 & 1337.9 & $3.28 \mathrm{E}-03$ & 389.9 & $9.55 \mathrm{E}-04$ & 297.4 & $7.28 \mathrm{E}-04$ & 248.0 & $6.07 \mathrm{E}-04$ \\
\hline 1.5 & 1663.8 & $5.39 \mathrm{E}-03$ & 447.6 & $1.45 \mathrm{E}-03$ & 330.6 & $1.07 \mathrm{E}-03$ & 270.5 & $8.76 \mathrm{E}-04$ \\
\hline 2.125 & 2987.3 & $1.29 \mathrm{E}-02$ & 733.2 & $3.17 \mathrm{E}-03$ & 523.8 & $2.26 \mathrm{E}-03$ & 420.2 & $1.82 \mathrm{E}-03$ \\
\hline 3 & 214.6 & $1.24 \mathrm{E}-03$ & 47.8 & $2.75 \mathrm{E}-04$ & 33.1 & $1.90 \mathrm{E}-04$ & 26.0 & $1.50 \mathrm{E}-04$ \\
\hline 4 & 0.9 & $6.69 \mathrm{E}-06$ & 0.2 & $1.37 \mathrm{E}-06$ & 0.1 & $9.25 \mathrm{E}-07$ & 0.1 & $7.18 \mathrm{E}-07$ \\
\hline Total & - & 0.0668 & - & 0.0215 & - & 0.0174 & - & 0.0152 \\
\hline
\end{tabular}


Table 14. Two-hour DDE Gamma Dose from Steel Scattering

\begin{tabular}{|c|c|c|c|c|c|c|c|c|}
\hline \multirow{3}{*}{$\begin{array}{l}\text { Gamma } \\
\text { Energy } \\
(\mathrm{MeV})\end{array}$} & \multicolumn{8}{|c|}{$8 \mathrm{~m}$} \\
\hline & \multicolumn{2}{|c|}{ Upper Sources } & \multicolumn{2}{|c|}{ Lower Point 1} & \multicolumn{2}{|c|}{ Lower Point 2} & \multicolumn{2}{|c|}{ Lower Point 3} \\
\hline & $\begin{array}{c}\phi_{\gamma} \\
\left(\gamma / \mathrm{cm}^{2} / \mathrm{s}\right)\end{array}$ & $\begin{array}{l}\text { Dose } \\
\text { (rem) }\end{array}$ & $\begin{array}{c}\phi_{\gamma} \\
\left(\gamma / \mathrm{cm}^{2} / \mathrm{s}\right)\end{array}$ & $\begin{array}{l}\text { Dose } \\
\text { (rem) }\end{array}$ & $\begin{array}{c}\phi_{\gamma} \\
\left(\gamma / \mathrm{cm}^{2} / \mathrm{s}\right)\end{array}$ & $\begin{array}{l}\text { Dose } \\
\text { (rem) }\end{array}$ & $\begin{array}{c}\phi_{\gamma} \\
\left(\gamma / \mathrm{cm}^{2} / \mathrm{s}\right)\end{array}$ & $\begin{array}{l}\text { Dose } \\
\text { (rem) }\end{array}$ \\
\hline 0.03 & 0.0 & - & 0.0 & - & 0.0 & - & 0.0 & - \\
\hline 0.04 & 0.0 & - & 0.0 & - & 0.0 & - & 0.0 & - \\
\hline 0.05 & 0.0 & - & 0.0 & - & 0.0 & - & 0.0 & - \\
\hline 0.0625 & 2.4 & $3.59 \mathrm{E}-07$ & 1.1 & $1.56 \mathrm{E}-07$ & 0.7 & $1.04 \mathrm{E}-07$ & 0.5 & $7.60 \mathrm{E}-08$ \\
\hline 0.08 & 1187.6 & $2.05 \mathrm{E}-04$ & 500.3 & $8.65 \mathrm{E}-05$ & 326.6 & $5.64 \mathrm{E}-05$ & 235.0 & $4.06 \mathrm{E}-05$ \\
\hline 0.1075 & 773.9 & $1.73 \mathrm{E}-04$ & 313.0 & $6.99 \mathrm{E}-05$ & 199.3 & $4.45 \mathrm{E}-05$ & 140.7 & $3.14 \mathrm{E}-05$ \\
\hline 0.15 & 5810.6 & $1.78 \mathrm{E}-03$ & 2221.4 & $6.80 \mathrm{E}-04$ & 1369.3 & 4.19E-04 & 944.3 & $2.89 \mathrm{E}-04$ \\
\hline 0.2125 & 18551.3 & $8.68 \mathrm{E}-03$ & 6610.9 & $3.09 \mathrm{E}-03$ & 3927.2 & $1.84 \mathrm{E}-03$ & 2636.9 & $1.23 \mathrm{E}-03$ \\
\hline 0.3 & 14861.4 & $1.02 \mathrm{E}-02$ & 4894.7 & $3.35 \mathrm{E}-03$ & 2801.8 & $1.92 \mathrm{E}-03$ & 1831.5 & $1.25 \mathrm{E}-03$ \\
\hline 0.4 & 7958.3 & $7.45 \mathrm{E}-03$ & 2445.0 & $2.29 \mathrm{E}-03$ & 1359.0 & $1.27 \mathrm{E}-03$ & 869.2 & $8.14 \mathrm{E}-04$ \\
\hline 0.5 & 4201.1 & $4.99 \mathrm{E}-03$ & 1222.7 & $1.45 \mathrm{E}-03$ & 665.5 & $7.91 \mathrm{E}-04$ & 418.6 & $4.97 \mathrm{E}-04$ \\
\hline 0.625 & 1924.4 & $2.84 \mathrm{E}-03$ & 531.5 & $7.84 \mathrm{E}-04$ & 283.6 & $4.19 \mathrm{E}-04$ & 175.4 & $2.59 \mathrm{E}-04$ \\
\hline 0.8 & 4038.0 & $7.56 \mathrm{E}-03$ & 1055.8 & $1.98 \mathrm{E}-03$ & 551.9 & $1.03 \mathrm{E}-03$ & 335.1 & $6.27 \mathrm{E}-04$ \\
\hline 1.075 & 1849.0 & $4.53 \mathrm{E}-03$ & 455.3 & $1.11 \mathrm{E}-03$ & 232.3 & $5.69 \mathrm{E}-04$ & 137.9 & $3.38 \mathrm{E}-04$ \\
\hline 1.5 & 2389.6 & $7.74 \mathrm{E}-03$ & 553.5 & $1.79 \mathrm{E}-03$ & 274.5 & $8.89 \mathrm{E}-04$ & 158.8 & $5.15 \mathrm{E}-04$ \\
\hline 2.125 & 4360.7 & $1.88 \mathrm{E}-02$ & 952.0 & $4.11 \mathrm{E}-03$ & 457.9 & $1.98 \mathrm{E}-03$ & 258.2 & $1.12 \mathrm{E}-03$ \\
\hline 3 & 311.9 & $1.80 \mathrm{E}-03$ & 64.4 & $3.71 \mathrm{E}-04$ & 30.0 & $1.73 \mathrm{E}-04$ & 16.6 & $9.54 \mathrm{E}-05$ \\
\hline 4 & 1.3 & $9.57 \mathrm{E}-06$ & 0.3 & $1.89 \mathrm{E}-06$ & 0.1 & $8.60 \mathrm{E}-07$ & 0.1 & $4.67 \mathrm{E}-07$ \\
\hline $120 \%$ Total & - & 0.0921 & - & 0.0254 & - & 0.0137 & - & 0.0085 \\
\hline
\end{tabular}

\begin{tabular}{|c|c|c|c|c|c|c|c|c|}
\hline \multirow{3}{*}{$\begin{array}{l}\text { Gamma } \\
\text { Energy } \\
(\mathrm{MeV})\end{array}$} & \multicolumn{8}{|c|}{$21 \mathrm{~m}$} \\
\hline & \multicolumn{2}{|c|}{ Upper Sources } & \multicolumn{2}{|c|}{ Lower Point 1} & \multicolumn{2}{|c|}{ Lower Point 2} & \multicolumn{2}{|c|}{ Lower Point 3} \\
\hline & $\begin{array}{c}\phi_{\gamma} \\
\left(\gamma / \mathrm{cm}^{2} / \mathrm{s}\right)\end{array}$ & $\begin{array}{l}\text { Dose } \\
\text { (rem) }\end{array}$ & $\begin{array}{c}\phi_{\gamma} \\
\left(\gamma / \mathrm{cm}^{2} / \mathrm{s}\right)\end{array}$ & $\begin{array}{l}\text { Dose } \\
\text { (rem) }\end{array}$ & $\begin{array}{c}\phi_{\gamma} \\
\left(\gamma / \mathrm{cm}^{2} / \mathrm{s}\right)\end{array}$ & $\begin{array}{l}\text { Dose } \\
\text { (rem) }\end{array}$ & $\begin{array}{c}\phi_{\gamma} \\
\left(\gamma / \mathrm{cm}^{2} / \mathrm{s}\right)\end{array}$ & $\begin{array}{l}\text { Dose } \\
\text { (rem) }\end{array}$ \\
\hline 0.03 & 0.0 & - & 0.0 & - & 0.0 & - & 0.0 & - \\
\hline 0.04 & 0.0 & - & 0.0 & - & 0.0 & - & 0.0 & - \\
\hline 0.05 & 0.0 & - & 0.0 & - & 0.0 & - & 0.0 & - \\
\hline 0.0625 & 4.0 & $5.89 \mathrm{E}-07$ & 1.4 & $2.03 \mathrm{E}-07$ & 0.8 & $1.12 \mathrm{E}-07$ & 0.5 & $7.33 \mathrm{E}-08$ \\
\hline 0.08 & 1930.3 & $3.34 \mathrm{E}-04$ & 651.4 & $1.13 \mathrm{E}-04$ & 354.1 & $6.12 \mathrm{E}-05$ & 229.7 & $3.97 \mathrm{E}-05$ \\
\hline 0.1075 & 1246.2 & $2.78 \mathrm{E}-04$ & 410.4 & $9.16 \mathrm{E}-05$ & 218.8 & $4.88 \mathrm{E}-05$ & 140.0 & $3.12 \mathrm{E}-05$ \\
\hline 0.15 & 9288.2 & $2.84 \mathrm{E}-03$ & 2951.8 & $9.03 \mathrm{E}-04$ & 1531.9 & $4.69 \mathrm{E}-04$ & 961.1 & $2.94 \mathrm{E}-04$ \\
\hline 0.2125 & 29654.6 & 1.39E-02 & 8981.3 & $4.20 \mathrm{E}-03$ & 4500.2 & $2.11 \mathrm{E}-03$ & 2757.2 & $1.29 \mathrm{E}-03$ \\
\hline 0.3 & 24073.4 & $1.65 \mathrm{E}-02$ & 6861.2 & $4.69 \mathrm{E}-03$ & 3298.5 & $2.26 \mathrm{E}-03$ & 1969.2 & $1.35 \mathrm{E}-03$ \\
\hline 0.4 & 13220.9 & $1.24 \mathrm{E}-02$ & 3541.5 & $3.31 \mathrm{E}-03$ & 1637.8 & $1.53 \mathrm{E}-03$ & 956.2 & $8.95 \mathrm{E}-04$ \\
\hline 0.5 & 7194.4 & $8.55 \mathrm{E}-03$ & 1822.5 & $2.17 \mathrm{E}-03$ & 816.2 & $9.70 \mathrm{E}-04$ & 468.5 & $5.57 \mathrm{E}-04$ \\
\hline 0.625 & 3432.7 & $5.07 \mathrm{E}-03$ & 816.4 & $1.21 \mathrm{E}-03$ & 353.8 & $5.22 \mathrm{E}-04$ & 199.8 & $2.95 \mathrm{E}-04$ \\
\hline 0.8 & 7629.7 & $1.43 \mathrm{E}-02$ & 1677.6 & $3.14 \mathrm{E}-03$ & 700.6 & $1.31 \mathrm{E}-03$ & 388.8 & $7.28 \mathrm{E}-04$ \\
\hline 1.075 & 3805.8 & $9.32 \mathrm{E}-03$ & 752.8 & $1.84 \mathrm{E}-03$ & 301.0 & $7.37 \mathrm{E}-04$ & 163.8 & $4.01 \mathrm{E}-04$ \\
\hline 1.5 & 5522.4 & $1.79 \mathrm{E}-02$ & 955.3 & $3.10 \mathrm{E}-03$ & 364.3 & $1.18 \mathrm{E}-03$ & 194.0 & $6.29 \mathrm{E}-04$ \\
\hline 2.125 & 11572.3 & $5.00 \mathrm{E}-02$ & 1716.1 & $7.41 \mathrm{E}-03$ & 624.5 & $2.70 \mathrm{E}-03$ & 325.0 & $1.40 \mathrm{E}-03$ \\
\hline 3 & 960.2 & $5.53 \mathrm{E}-03$ & 121.1 & $6.97 \mathrm{E}-04$ & 42.2 & $2.43 \mathrm{E}-04$ & 21.5 & $1.24 \mathrm{E}-04$ \\
\hline 4 & 4.7 & $3.35 \mathrm{E}-05$ & 0.5 & $3.68 \mathrm{E}-06$ & 0.2 & $1.24 \mathrm{E}-06$ & 0.1 & $6.18 \mathrm{E}-07$ \\
\hline $102 \%$ Total & - & 0.1600 & - & 0.0335 & - & 0.0144 & - & 0.0082 \\
\hline
\end{tabular}




\subsection{Total Effective Dose Equivalent (TEDE)}

Table 15 shows the estimated doses from all modes of radiation release for the reference case of 7.35 MW power level after 4200 MWD operation. As indicated in the previous section, the TEDE dose coefficients (or conversion factors) are adopted for the radiation release estimations. It is seen that the primary contribution to the total TEDE dose is from the scattering terms, which is very similar to the current MITR SAR. The overall dose is $302.1 \mathrm{mrem}$ total TEDE at $8 \mathrm{~m} \mathrm{EAB}$ and a higher dose of $392.8 \mathrm{mrem}$ total TEDE is found at $21 \mathrm{~m}$ EAB. As mentioned in the current MITR SAR, the maximum dose peaks at $16 \mathrm{~m}$ with about $21 \%$ increase in addition to the $21 \mathrm{~m}$ dose level [1]. By taking into account this effect, the maximum dose from the 19B25 LEU core MHA is still less than 480 mrem total TEDE, which is under the 500 mrem total TEDE limit goal for public exposure cited from NUREG-1537 [7].

\section{Table 15. Estimated Doses (TEDE Method) from all Modes of Radiation Release during an MITR (19B25 LEU Core) Maximum Hypothetical Accident}

\begin{tabular}{|l|c|c|}
\hline \multirow{2}{*}{ Component of the Dose } & \multicolumn{2}{|c|}{ Dose (mrem) } \\
\cline { 2 - 3 } & $8 \mathrm{~m}$ & $21 \mathrm{~m}$ \\
\hline \hline Leakage TEDE & 8.2 & 8.1 \\
Gamma DDE & & \\
$\quad$ Steel Dome Penetration & 3.3 & 25.1 \\
Shadow Shield Penetration & 47.9 & 22.5 \\
Air Scattering & 103.1 & 120.9 \\
Steel Scattering & 139.7 & 216.1 \\
Total TEDE & 302.1 & 392.8 \\
\hline
\end{tabular}

\subsection{Comparison to Reference HEU Core}

A comparison of the estimated dose release to the reference HEU core is made in this sub-section. Since there are 15 plates (instead of 19 plates in 19B25 LEU fuel) in the reference HEU fuel element, melting of 4 plates is considered as the consequence of the MHA [1]. Except a different source term comparing to the current LEU study, the same methodology is used for quantifying the release fractions and determining the release paths. As seen in Table 16, the estimated total TEDE doses at $8 \mathrm{~m}$ and $21 \mathrm{~m}$ EABs are 273.7 and $360.2 \mathrm{mrem}$, respectively. Comparing Tables 15 and 16, one can find an approx. $10 \%$ MHA dose release increase due to the LEU conversion. The increase is roughly the same magnitude of the power uprate from $6 \mathrm{MW}$ (HEU) to 7 MW (LEU). As expected, the increase is lessened to some extent by the thinner LEU fuel in outer plates which serves to lower the five-plate radial peaking factor. 
Table 16. Estimated Doses (TEDE Method) from all Modes of Radiation Release during an MITR (Reference HEU Core) Maximum Hypothetical Accident

\begin{tabular}{|l|c|c|}
\hline \multirow{2}{*}{ Component of the Dose } & \multicolumn{2}{|c|}{ Dose (mrem) } \\
\cline { 2 - 3 } & $8 \mathrm{~m}$ & $21 \mathrm{~m}$ \\
\hline \hline Containment Leakage TEDE & 7.8 & 7.8 \\
Gamma DDE & & \\
$\quad$ Steel Dome Penetration & 3.2 & 24.5 \\
Shadow Shield Penetration & 50.1 & 23.6 \\
Air Scattering & 87.0 & 104.6 \\
Steel Scattering & 125.6 & 199.8 \\
Total TEDE & 273.7 & 360.2 \\
\hline
\end{tabular}

\section{CONCLUSIONS}

This study updates the off-site radiation dose to the public during a Maximum Hypothetical Accident (MHA) at the MITR for the 19B25 LEU fueled core. The Total Effective Dose Equivalent (TEDE) dose level has been calculated for a two-hour period at the exclusion area boundaries (EABs). The MHA is conservatively assumed to occur at the MITR with 7.35 MW power level (5\% overpower due to uncertainty in power measurement) after 4200 MWD operation. The release fractions from fuel to containment are mostly adopted from the MITR SAR; whereas proposed in the current study are full release of noble gases, and a linear evaporation process for the coolant-to-containment radionuclides transport. The methodology and the dispersion coefficients for atmospheric dispersions from stack release and containment leakage also remain the same as in the current MITR safety analysis. The considered paths for gamma dose include: a) direct gamma flux through steel dome penetration, b) direct gamma flux through shadow shield penetration, c) scattered gamma flux after interaction with air, and d) scattered gamma flux after interaction with steel dome.

The overall dose is 302.1 mrem total TEDE at the $8 \mathrm{~m} \mathrm{EAB}$ and a higher dose of $392.8 \mathrm{mrem}$ total TEDE is found at the $21 \mathrm{~m} \mathrm{EAB}$. As mentioned in the current MITR SAR, the maximum dose peaks at $16 \mathrm{~m}$ with about $21 \%$ increase in addition to the $21 \mathrm{~m}$ dose level [1]. By taking into account this effect, the maximum dose from the 19B25 LEU core MHA is still less than 480 mrem total TEDE, which is below the 500 mrem total TEDE limit goal for public exposure cited from NUREG-1537 [7].

\section{ACKNOWLEDGMENTS}

This research is sponsored by the U.S. Department of Energy, National Nuclear Security Administration Office of Material Management and Minimization Reactor Conversion Program.

\section{REFERENCES}

[1] MITR-Staff, Safety Analysis Report for the MIT Research Reactor, MIT-NRL-11-01, 2011, MIT Nuclear Reactor Laboratory.

[2] T.H. Newton, Jr., Development of a Low Enrichment Uranium Core for the MIT Reactor, PhD Thesis, 2006, Massachusetts Institute of Technology. 
[3] T.H. Newton, Jr., M.S. Kazimi, and E.E. Pilat, Development of a low-enriched-uranium core for the MIT reactor. Nucl. Sci. Eng., 2007. 157(3): p. 264-279.

[4] K. Sun, et al., Accident analyses for conversion of the MIT Research Reactor (MITR) from highly enriched uranium to low enriched uranium using an unfinned fuel element. MIT-NRL-14-04 Rev. 1, November 2014, MIT Nuclear Reactor Laboratory.

[5] T.H. Newton, Jr., E.H. Wilson, A. Bergeron, N. Horelik, and J.G. Stevens, "Neutronic Analyses for HEU to LEU Fuel Conversion of the Massachusetts Institute of Technology MITR Reactor," ANL/RERTR/TM-10-40, Argonne National Laboratory, December 2010.

[6] A. Bergeron, E.H. Wilson, G. Yesilyurt, F.E. Dunn, J.G. Stevens, L. Hu, and T. H. Newton, "Low Enriched Uranium Core Design for the Massachusetts Institute of Technology Reactor (MITR) with Un-finned 12 mil-thick Clad UMo Monolithic Fuel”, ANL/GTRI/TM-13/15, Argonne National Laboratory, November 2013.

[7] U.S. Nuclear Regulatory Commission. NUREG-1537 - Guidelines for Preparing and Reviewing Applications for the Licensing of Non-Power Reactors, 1996.

[8] 10 CFR Part 20.1301 - Dose limits for individual members of the public, 2002.

[9] R. Mull, Exclusion Area Radiation Release during the MIT Reactor Design Basis Accident, Master Thesis, 1977, Massachusetts Institute of Technology.

[10] Q. Li, Estimate of Radiation Release for MIT Research Reactor during Design Basis Accident, Master Thesis, 1998, Massachusetts Institute of Technology.

[11] K. Plumer, Estimate of Radiation Release from MIT Reactor with Low Enriched Uranium (LEU) Core during Maximum Hypothetical Accident, Master Thesis, 2011, Massachusetts Institute of Technology.

[12] 5. K. Sun, M. Ames, T. Newton, L. Hu. Validation of a fuel management code MCODE-FM against fission product poisoning and flux wire measurement of the MIT Reactor. Progress in Nuclear Energy, vol. 75: pp. 42-48, 2014.

[13] Regulatory Guide 1.183 - Alternative Radiological Source Terms for Evaluating Design Basis Accidents at Nuclear Power Reactors, 2000. 
APPENDIX: NORMALIZED 238-GROUP NEUTRON FLUX USED IN COUPLE CODE

\begin{tabular}{|c|c|c|c|c|c|}
\hline $5.464 \mathrm{E}-10$ & $1.688 \mathrm{E}-09$ & 3.140E-09 & 4.700E-09 & $1.185 \mathrm{E}-08$ & $1.655 \mathrm{E}-07$ \\
\hline $5.225 \mathrm{E}-07$ & $1.898 \mathrm{E}-06$ & 5.807E-06 & $3.456 \mathrm{E}-06$ & $1.658 \mathrm{E}-05$ & $1.236 \mathrm{E}-05$ \\
\hline $4.084 \mathrm{E}-06$ & $1.686 \mathrm{E}-05$ & $1.531 \mathrm{E}-05$ & $5.091 \mathrm{E}-06$ & $2.128 \mathrm{E}-06$ & $2.108 \mathrm{E}-06$ \\
\hline $3.797 \mathrm{E}-06$ & $2.976 \mathrm{E}-06$ & 5.931E-06 & 5.554E-06 & $5.826 \mathrm{E}-06$ & $1.471 \mathrm{E}-06$ \\
\hline $1.830 \mathrm{E}-06$ & $1.054 \mathrm{E}-06$ & $3.320 \mathrm{E}-06$ & $6.294 \mathrm{E}-06$ & $6.936 \mathrm{E}-06$ & $8.742 \mathrm{E}-07$ \\
\hline $6.732 \mathrm{E}-06$ & $2.680 \mathrm{E}-06$ & $2.297 \mathrm{E}-06$ & $5.178 \mathrm{E}-06$ & $3.172 \mathrm{E}-06$ & $2.857 \mathrm{E}-06$ \\
\hline $1.776 \mathrm{E}-06$ & $2.140 \mathrm{E}-06$ & 8.777E-06 & $8.214 \mathrm{E}-06$ & $1.044 \mathrm{E}-05$ & $8.331 \mathrm{E}-06$ \\
\hline $4.560 \mathrm{E}-06$ & $6.182 \mathrm{E}-06$ & $3.113 \mathrm{E}-06$ & $7.406 \mathrm{E}-07$ & $2.195 \mathrm{E}-06$ & $6.639 \mathrm{E}-07$ \\
\hline $4.229 \mathrm{E}-06$ & $2.742 \mathrm{E}-06$ & $7.238 \mathrm{E}-07$ & $1.893 \mathrm{E}-06$ & $6.695 \mathrm{E}-06$ & $3.243 \mathrm{E}-06$ \\
\hline 6.019E-06 & 3.993E-06 & $4.518 \mathrm{E}-06$ & $2.359 \mathrm{E}-06$ & $4.024 \mathrm{E}-06$ & 5.783E-06 \\
\hline 5.599E-07 & $2.893 \mathrm{E}-06$ & $1.941 \mathrm{E}-06$ & $1.550 \mathrm{E}-06$ & 5.109E-07 & $2.563 \mathrm{E}-06$ \\
\hline $1.885 \mathrm{E}-06$ & $4.051 \mathrm{E}-07$ & $3.301 \mathrm{E}-06$ & $2.326 \mathrm{E}-06$ & $3.960 \mathrm{E}-06$ & $2.170 \mathrm{E}-07$ \\
\hline $2.316 \mathrm{E}-06$ & $6.735 \mathrm{E}-06$ & $7.621 \mathrm{E}-07$ & $1.892 \mathrm{E}-06$ & $1.432 \mathrm{E}-06$ & 5.374E-08 \\
\hline 8.394E-07 & $3.883 \mathrm{E}-07$ & 4.433E-06 & $2.585 \mathrm{E}-07$ & $3.091 \mathrm{E}-07$ & $6.602 \mathrm{E}-07$ \\
\hline 7.353E-07 & $1.063 \mathrm{E}-06$ & $9.321 \mathrm{E}-07$ & $2.174 \mathrm{E}-07$ & $5.271 \mathrm{E}-07$ & 5.317E-07 \\
\hline $6.259 \mathrm{E}-07$ & $2.973 \mathrm{E}-07$ & $6.376 \mathrm{E}-07$ & 3.294E-07 & $9.025 \mathrm{E}-07$ & $2.502 \mathrm{E}-07$ \\
\hline $2.329 \mathrm{E}-07$ & $2.559 \mathrm{E}-07$ & $1.671 \mathrm{E}-07$ & $2.482 \mathrm{E}-07$ & $3.140 \mathrm{E}-07$ & $1.375 \mathrm{E}-07$ \\
\hline $3.717 \mathrm{E}-07$ & 2.952E-07 & $3.206 \mathrm{E}-07$ & $9.215 \mathrm{E}-08$ & $2.561 \mathrm{E}-07$ & $1.898 \mathrm{E}-07$ \\
\hline $2.413 \mathrm{E}-07$ & $1.604 \mathrm{E}-07$ & $1.758 \mathrm{E}-07$ & $1.060 \mathrm{E}-07$ & $3.923 \mathrm{E}-07$ & $1.458 \mathrm{E}-07$ \\
\hline $3.736 \mathrm{E}-07$ & $7.844 \mathrm{E}-07$ & $8.342 \mathrm{E}-07$ & $8.554 \mathrm{E}-07$ & $5.148 \mathrm{E}-07$ & $2.446 \mathrm{E}-07$ \\
\hline $3.290 \mathrm{E}-07$ & $2.149 \mathrm{E}-07$ & $7.090 \mathrm{E}-07$ & $4.826 \mathrm{E}-07$ & 4.784E-07 & 3.979E-07 \\
\hline $3.324 \mathrm{E}-07$ & $5.570 \mathrm{E}-07$ & 5.591E-07 & $2.191 \mathrm{E}-07$ & $1.145 \mathrm{E}-06$ & $7.235 \mathrm{E}-07$ \\
\hline $7.507 \mathrm{E}-07$ & 9.869E-07 & $1.239 \mathrm{E}-07$ & $1.568 \mathrm{E}-07$ & $4.023 \mathrm{E}-08$ & $1.675 \mathrm{E}-07$ \\
\hline $2.652 \mathrm{E}-07$ & $7.147 \mathrm{E}-07$ & 4.995E-07 & $3.386 \mathrm{E}-07$ & $1.303 \mathrm{E}-06$ & 5.334E-07 \\
\hline $4.241 \mathrm{E}-07$ & $7.606 \mathrm{E}-07$ & $2.245 \mathrm{E}-07$ & $1.195 \mathrm{E}-07$ & 7.341E-08 & $2.517 \mathrm{E}-07$ \\
\hline $2.634 \mathrm{E}-07$ & $2.766 \mathrm{E}-07$ & 2.882E-07 & $3.001 \mathrm{E}-07$ & $2.803 \mathrm{E}-07$ & $2.578 \mathrm{E}-07$ \\
\hline $3.003 \mathrm{E}-07$ & $3.125 \mathrm{E}-07$ & $4.081 \mathrm{E}-07$ & $2.210 \mathrm{E}-07$ & $3.137 \mathrm{E}-07$ & 3.724E-07 \\
\hline $3.925 \mathrm{E}-07$ & $4.136 \mathrm{E}-07$ & $4.376 \mathrm{E}-07$ & $2.547 \mathrm{E}-07$ & $2.626 \mathrm{E}-07$ & $2.711 \mathrm{E}-07$ \\
\hline 2.792E-07 & $2.848 \mathrm{E}-07$ & $1.157 \mathrm{E}-07$ & $1.704 \mathrm{E}-07$ & $1.108 \mathrm{E}-07$ & $1.644 \mathrm{E}-07$ \\
\hline $5.424 \mathrm{E}-08$ & 5.462E-08 & 5.554E-08 & 5.619E-08 & $5.696 \mathrm{E}-08$ & 5.767E-08 \\
\hline $5.852 \mathrm{E}-08$ & 5.949E-08 & $6.052 \mathrm{E}-08$ & $6.169 \mathrm{E}-08$ & $6.268 \mathrm{E}-08$ & $6.372 \mathrm{E}-08$ \\
\hline $6.443 \mathrm{E}-08$ & $6.530 \mathrm{E}-08$ & $6.690 \mathrm{E}-08$ & $1.712 \mathrm{E}-07$ & $1.770 \mathrm{E}-07$ & $1.821 \mathrm{E}-07$ \\
\hline $1.875 \mathrm{E}-07$ & 3.952E-07 & 4.196E-07 & $4.476 \mathrm{E}-07$ & 4.793E-07 & $5.106 \mathrm{E}-07$ \\
\hline $2.717 \mathrm{E}-07$ & $2.814 \mathrm{E}-07$ & 5.931E-07 & $6.436 \mathrm{E}-07$ & $6.929 \mathrm{E}-07$ & 7.444E-07 \\
\hline $3.906 \mathrm{E}-07$ & $4.041 \mathrm{E}-07$ & 4.123E-07 & $4.232 \mathrm{E}-07$ & $4.520 \mathrm{E}-07$ & 4.967E-07 \\
\hline $5.568 \mathrm{E}-07$ & $6.366 \mathrm{E}-07$ & 7.444E-07 & $8.922 \mathrm{E}-07$ & $1.108 \mathrm{E}-06$ & $1.418 \mathrm{E}-06$ \\
\hline $6.841 \mathrm{E}-07$ & $7.564 \mathrm{E}-07$ & $8.383 \mathrm{E}-07$ & $9.147 \mathrm{E}-07$ & 9.762E-07 & $1.009 \mathrm{E}-06$ \\
\hline $9.598 \mathrm{E}-07$ & $4.113 \mathrm{E}-07$ & $9.755 \mathrm{E}-07$ & $8.138 \mathrm{E}-08$ & $6.041 \mathrm{E}-08$ & $1.532 \mathrm{E}-08$ \\
\hline $1.305 \mathrm{E}-08$ & 5.497E-09 & $2.601 \mathrm{E}-09$ & $2.033 \mathrm{E}-09$ & $1.245 \mathrm{E}-09$ & $6.809 \mathrm{E}-10$ \\
\hline $7.939 \mathrm{E}-10$ & $2.025 \mathrm{E}-10$ & $1.093 \mathrm{E}-10$ & $1.789 \mathrm{E}-12$ & $\mathrm{e}$ & $\mathrm{t}$ \\
\hline
\end{tabular}

